\title{
Spatial and tidal variation in food supply to shallow cold-water coral reefs of the Mingulay Reef complex (Outer Hebrides, Scotland)
}

\author{
Gerard C.A. Duineveld ${ }^{1, *}$, Rachel M. Jeffreys ${ }^{1,2}$, Marc S.S. Lavaleye ${ }^{1}$, \\ Andrew J. Davies ${ }^{3}$, Magda J.N. Bergman ${ }^{1}$, Thalia Watmough ${ }^{1}$, Rob Witbaard ${ }^{1}$ \\ ${ }^{1}$ Royal Netherlands Institute for Sea Research, PO Box 59, 1790 AB Den Burg, Texel, The Netherlands \\ ${ }^{2}$ School of Environmental Sciences, University of Liverpool, 4 Brownlow Street, Liverpool, L69 3GP, UK \\ ${ }^{3}$ School of Ocean Sciences, Bangor University, Menai Bridge, Anglesey LL59 5AB, UK
}

\begin{abstract}
The finding of a previously undescribed cold-water coral reef (Banana Reef) in the Scottish Mingulay reef complex, with denser coverage of living Lophelia pertusa than the principal Mingulay 1 Reef, was the incentive for a comparative study of the food supply to the 2 reefs. Suspended particulate matter (SPM) samples from the surface and bottom water covering a tidal cycle were compared with respect to lipids, pigments, and $\delta^{13} \mathrm{C}$ and $\delta^{15} \mathrm{~N}$. Lipid profiles and stable isotope signatures of SPM were compared with those of coral tissue samples. Concurrently, hydrographic measurements were conducted to track the movement of the water masses across both reefs. Between-reef differences in SPM lipid concentrations were small compared to those in coral tissue. Corals at Banana Reef had lower lipid concentrations, pointing to less favourable food conditions than at Mingulay 1. Stable isotopes signatures and lipid profiles showed that corals on both reefs feed primarily on surface algal matter, within the timeframe of our study. At Mingulay 1, fresh microalgae are supplied to the coral reef by local downwelling. This downwelling pulse is tidally advected to Banana Reef. Food conditions observed during this study at both reefs do not explain the between-reef difference in coral coverage. A speculative explanation for the denser coral coverage at the deeper Banana Reef encompasses the slightly lower temperature that exhibits lower metabolic stress on corals, in combination with a higher current speed and particle encounter rate.
\end{abstract}

KEY WORDS: Lophelia pertusa - Cold-water corals - Suspended particulate organic matter · Food supply $\cdot$ Internal wave $\cdot$ Downwelling

\section{INTRODUCTION}

The cold-water coral (CWC) Lophelia pertusa has a cosmopolitan distribution throughout the world's oceans (Davies \& Guinotte 2011). The majority of records originate from the Northeast (NE) Atlantic Ocean, an area that appears to be highly suited for its growth (Davies et al. 2008, Davies \& Guinotte 2011). Cold-water coral habitats in the NE Atlantic can have different forms, such as isolated coral thickets, extensive cover on top of carbonate build-ups and 3-dimensional, reef-like structures. In all cases the presence of coral colonies promotes local species richness, abundance and biomass (e.g. Jensen \& Frederiksen 1992, Jonsson et al. 2004, Lessard-Pilon et al. 2010). As a result of this elevated biodiversity, L. pertusa habitats have become a focus for protection, since these fragile structures are vulnerable to bottom trawling (Hall-Spencer et al. 2002). Fishing affects both deep ( $>600 \mathrm{~m}_{i}$ e.g. Rockall or Porcupine Bank) and shallow ( $<200 \mathrm{~m}$; e.g. Norway or UK) coral habitats (Benn et al. 2010). Protected CWC habitats 
were initially confined to Norwegian and Canadian waters, but are now also found in exclusive economic zones (EEZs) of other countries and on the High Seas (Hall-Spencer et al. 2009).

The Mingulay Reef complex is the only CWC habitat discovered in the inshore region of the UK to date. It is located in the Sea of the Hebrides within the southern part of the deep-water channel that lies between the Outer Hebrides and the Scottish mainland (Fig. 1A). The reef complex has been the subject of several interdisciplinary studies in the framework of the EU-funded HERMES and
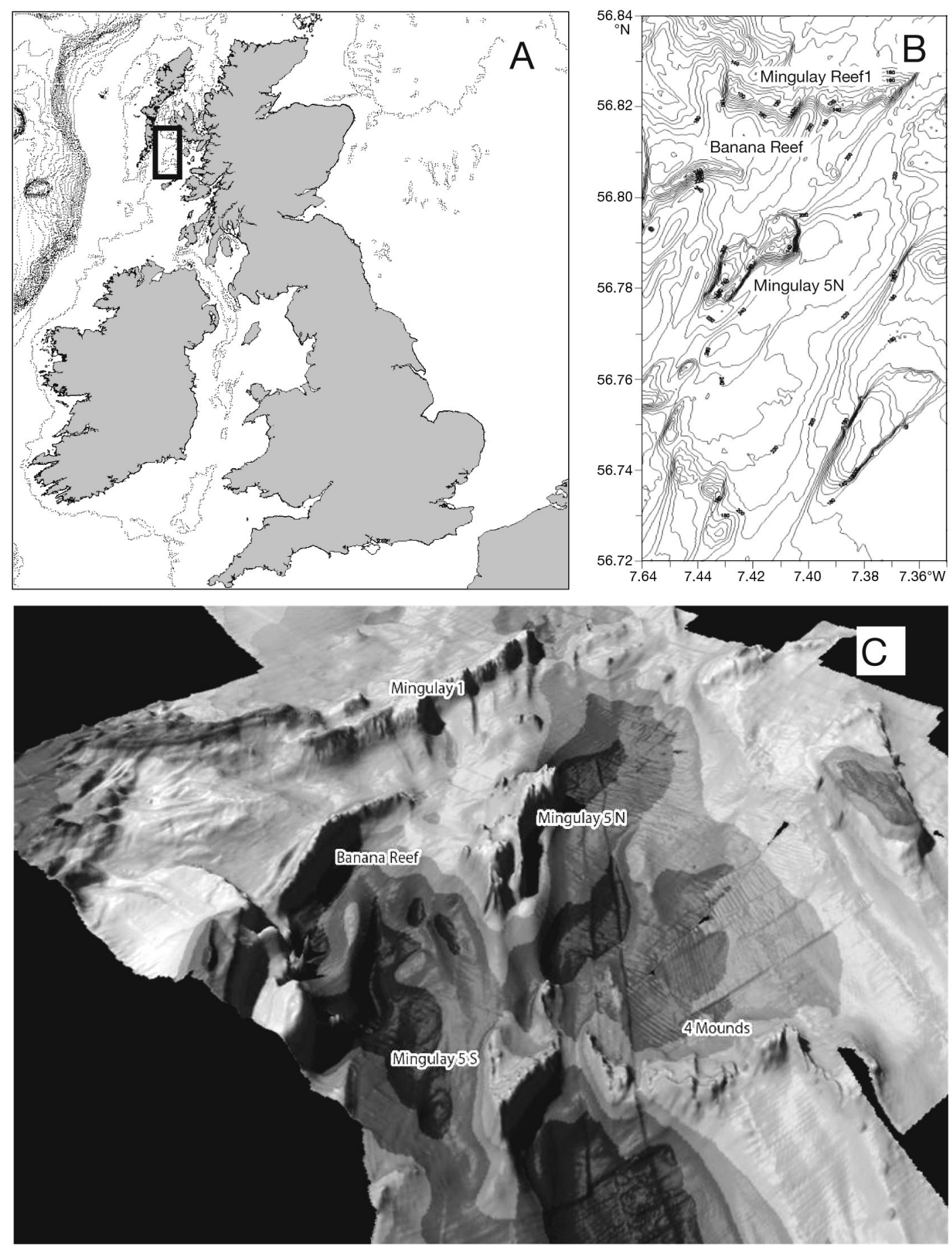

Fig. 1. (A) The Mingulay Reef complex east off the Outer Hebrides (Scotland), demarked in bold. (B) Detailed map shows locations of different reef areas. (C) Three-dimensional bathymetry map of the Reef complex based on multibeam data 
HERMIONE projects (Weaver et al. 2004, 2009) the results of which have been reviewed by Roberts et al. (2009). The best-known reef within the complex is the Mingulay 1 Reef (Fig. 1B,C) where community structure and biodiversity patterns have been studied by Roberts et al. (2005) and Henry et al. (2010). During a cruise in summer 2006 with RV Pelagia, we studied the hydrography and food supply on Mingulay 1 using CTD and benthic landers equipped with turbidity, fluorescence, and current sensors. The data showed that during ebb and flood periods the bank on which the reef grows is responsible for the development of an internally-driven hydraulic jump. During slack tides, this internal wave propagates over the reef causing downwelling of warm surface water with a relatively high fluorescent content (Davies et al. 2009). This tidally recurring pulse of phytoplankton was hypothesised to at least partially fuel the corals, possibly in addition to the organic fraction of near-bed suspended particulate matter (SPM) advected over Mingulay 1 Reef during peak tides (Davies et al. 2009). Recently, Dodds et al. (2009) argued, on the basis of fatty acid profiles, that zooplankton forms a major food item for the corals on Mingulay 1.

Our initial investigation in 2006 revealed a new reef that was named Banana Reef due to its shape (Fig. 1B,C). At first inspection there were clear differences between Mingulay 1 Reef and Banana Reefs, with respect to both coral cover and reef topography. Live coral seemed to be more abundant on Banana Reef despite its reef top lying $\sim 25 \mathrm{~m}$ deeper than Mingulay 1 . This motivated us to make a comparative study of the 2 reefs with the following aims: (1) to map the coral and epifauna community using a tethered video system; (2) to establish if between-reef differences in coral cover were related to differences in food supply mechanisms and food resources. In search of the physical mechanisms supplying food to the coral communities, we deployed moorings with current meters, fluorometers, and turbidity sensors on both reefs during summer 2007. In conjunction with this, we analysed stable carbon and nitrogen isotopes $\left(\delta^{13} \mathrm{C}\right.$ and $\left.\delta^{15} \mathrm{~N}\right)$, lipids, and phytopigments in the organic fraction of suspended particles (SPM) and in coral tissues.

$\delta^{13} \mathrm{C}$ and $\delta^{15} \mathrm{~N}$ provide information on nutritional sources and trophic positioning within a food web (Fry \& Sherr 1984, Fry 2006). Lipids provide information about the source, transformation, and age of organic matter (Santos et al. 1994, Wakeham et al. 1997, Kiriakoulakis et al. 2004, Jeffreys et al. 2009) and are a group of compounds essential for repro- duction, growth and maintenance of organisms. Additionally, fatty acids (e.g. phytoplankton polyunsaturated FAs) are useful trophic biomarkers as they are conserved during trophic transfer (Volkman et al. 1998, Dalsgaard et al. 2003). Phytopigments have been widely applied to determine contributions of particular phytoplankton species to fluxes of organic matter using the source specificity of carotenoids and to determine the freshness of particulate organic matter using chlorophyll $a$ and its degradation products (e.g. Lee et al. 2000, Duineveld et al. 2004, Schubert et al. 2005).

In this manuscript, we present novel data on the coral community and associated food resources on both Mingulay 1 Reef and the newly discovered Banana Reef.

\section{MATERIALS AND METHODS}

\section{Multibeam and video surveys}

In August 2006, the wider Mingulay area was mapped using a hull-mounted Kongsberg-Simrad EM300 multibeam echosounder at $30 \mathrm{kHz}$. The echosounder used 135 beams per ping over a maximum coverage sector of $150^{\circ}$ (beam spacing was equidistant). This survey greatly extended the coverage of the 2003 survey (Roberts et al. 2005), filled several large gaps, and led to the discovery of several new reefs areas, including Banana Reef, which was the closest to Mingulay 1 (Fig. 1C). The 2006 multibeam survey produced 2 types of data, the first being a tidally corrected bathymetric map and the second, a map of the strength of acoustic backscatter. After ground-truthing the backscatter with known coral records, a working map of the area was drawn showing the distribution of different acoustic classes, including those assigned to coral.

Areas with known and suspected coral cover were surveyed using a tethered digital video system with a real-time relay to the vessel. The height of the video system above the seabed ( 1 to $5 \mathrm{~m}$ ) was controlled by a winch operator watching the video relay. A pair of parallel Oktopus green laser lights, separated by a distance of $30 \mathrm{~cm}$, was attached to the video system to enable estimation of absolute sizes of objects. Time, date, and geographic coordinates of the camera location were recorded by a GPS antenna mounted close to the winch and captured on the video footage. A total of 11 video transects were captured, varying in length from 770 to $3700 \mathrm{~m}$. A total distance of $21.4 \mathrm{~km}$ was covered by video, amounting to $17 \mathrm{~h}$ 


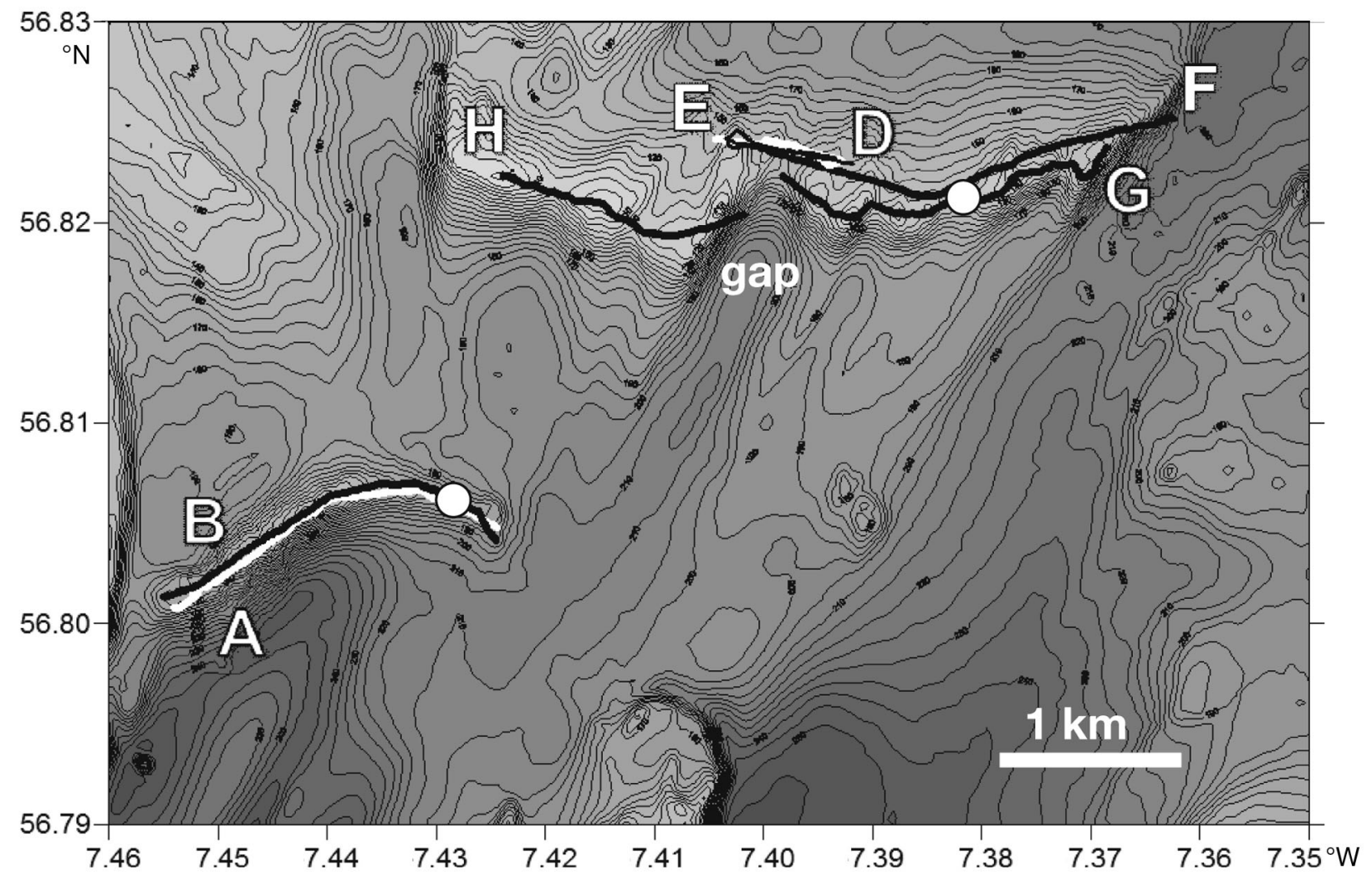

Fig. 2. Tracks of videosurveys made on Banana Reef (A, B) and Mingulay Reef 1 (D, E, F, G, H). Track A and E in white, all others in black. O: position of the 2 long-term moorings

Table 1. Video transect details. Time is local time

\begin{tabular}{|c|c|c|c|c|c|c|c|}
\hline Transect & $\begin{array}{c}\text { Date } \\
\mathrm{dd} / \mathrm{mm} / \text { yyyy }\end{array}$ & \multicolumn{2}{|c|}{ Time } & \multicolumn{2}{|c|}{ Position } & $\begin{array}{l}\text { Total length } \\
\text { (m) }\end{array}$ & $\begin{array}{l}\text { Depth range } \\
(\mathrm{m})\end{array}$ \\
\hline A & $14 / 08 / 2006$ & $15: 14: 38$ & $17: 14: 47$ & $\begin{array}{c}56.8008 \mathrm{~N} \\
7.454 \mathrm{~W}\end{array}$ & $\begin{array}{r}56.8048 \mathrm{~N} \\
7.4244 \mathrm{~W}\end{array}$ & 2343 & $129-180$ \\
\hline B & $15 / 08 / 2006$ & 16:11:13 & $18: 17: 24$ & $\begin{array}{c}56.8008 \mathrm{~N} \\
7.454 \mathrm{~W}\end{array}$ & $\begin{array}{r}56.8048 \mathrm{~N} \\
7.4244 \mathrm{~W}\end{array}$ & 2300 & $129-184$ \\
\hline $\mathrm{D}$ & $22 / 08 / 2006$ & $13: 37: 03$ & $15: 20: 06$ & $\begin{array}{r}56.8242 \mathrm{~N} \\
7.4035 \mathrm{~W}\end{array}$ & $\begin{array}{r}56.823 \mathrm{~N} \\
7.392 \mathrm{~W}\end{array}$ & 2286 & $120-151$ \\
\hline E & $22 / 08 / 2006$ & $10: 28: 00$ & 11:13:21 & $\begin{array}{r}56.8242 \mathrm{~N} \\
7.4042 \mathrm{~W}\end{array}$ & $\begin{array}{r}56.8231 \mathrm{~N} \\
7.3928 \mathrm{~W}\end{array}$ & 1329 & $120-151$ \\
\hline F & $20 / 08 / 2006$ & $09: 21: 26$ & 11:15:23 & $\begin{array}{l}56.824 \mathrm{~N} \\
7.4016 \mathrm{~W}\end{array}$ & $\begin{array}{r}56.8252 \mathrm{~N} \\
7.3625 \mathrm{~W}\end{array}$ & 2608 & 119-206 \\
\hline $\mathrm{G}$ & $19 / 08 / 2006$ & $12: 36: 09$ & $14: 27: 35$ & $\begin{array}{c}56.8224 \mathrm{~N} \\
7.3983 \mathrm{~W}\end{array}$ & $\begin{array}{r}56.8238 \mathrm{~N} \\
7.3685 \mathrm{~W}\end{array}$ & 2352 & $105-153$ \\
\hline $\mathrm{H}$ & 19/08/2006 & 09:47:03 & 11:00:55 & $\begin{array}{c}56.8223 \mathrm{~N} \\
7.4238 \mathrm{~W}\end{array}$ & $\begin{array}{r}56.8204 \mathrm{~N} \\
7.4017 \mathrm{~W}\end{array}$ & 1528 & $93-171$ \\
\hline
\end{tabular}

of footage. This study describes transects on the new Banana Reef (A \& B) and 5 transects across the Mingulay 1 area (D, E, F, G \& H) (Fig. 2). Details of the video transects are given in Table 1.
After transferring the GPS information of each track into a GIS, total length of coral cover (in m) along each transect was estimated by adding the distances that live coral was seen on the entire video 
transect. Subsequently, each video transect line was sub-divided into sub-transects of $25 \pm 2 \mathrm{~m}$ length in a GIS. The footage for each sub-transect was then digitized and classified according to the multi-layered scheme adapted from Wienberg et al. (2008) (Table 2). The dominant underlying substratum type (facies), and presence or absence of biocoenoses (live and dead coral framework, megafauna) and external features were recorded, and plotted in a GIS. Each sub-transect was assigned 1 of 13 habitat codes based on the 13 different combinations of facies, biocoenoses or features observed (Table 3 ).

The relationship between megafauna and habitats in the study area was explored by clustering habitats recorded from all sub-transects on the basis of their megafauna species counts. This showed which habitat type had the most homogenous megafauna composition and which species were important contributors to the grouping. Differences in megafaunal community structure between reefs were determined via CLUSTER and ANOSIM analyses in the PRIMER 6 software package (Clarke \& Warwick 2001). SIMPER analyses were then used to determine the species responsible for these dissimilarities.

\section{Hydrography}

On 27 June 2007, 2 moorings were deployed for $\sim 3$ mo (Fig. 2): one on the eastern terminus of Banana Reef $\left(56^{\circ} 48.38^{\prime} \mathrm{N}, 7^{\circ} 25.71^{\prime} \mathrm{W}\right)$ at $159 \mathrm{~m}$ water depth, equipped with an Aanderaa RCM9 current meter at $4 \mathrm{~m}$ above bottom (mab) as well as a Seapoint OBSFluorometer connected to a data logger at $3.1 \mathrm{mab}$, and one on top of the eastern part of Mingulay 1 Reef $\left(56^{\circ} 49.27^{\prime} \mathrm{N}, 7^{\circ} 22.91^{\prime} \mathrm{W}\right)$ at $135 \mathrm{~m}$ water depth. This mooring was equipped with an Aanderaa RCM 7 current meter and a WetLabs OBS-Fluorometer. Instruments were placed at similar heights above the seafloor as on Banana Reef. Both fluorometers were operationally calibrated against the (calibrated) output of the fluorometer (Chelsea Aqua 3) mounted on the CTD system of RV Pelagia.

The synchronicity between the variables measured with the moorings (temperature, fluorescence, and turbidity) was assessed using cross-correlation function (CCF) analysis using SYSTAT 12 (cf. Davies et al. 2009). CCF measures the correlation between 2 time-series with different time offsets (lag). The cross-correlation values between variables were plotted as a function of lag interval (in h). Positive correlations represent the primary axis offset

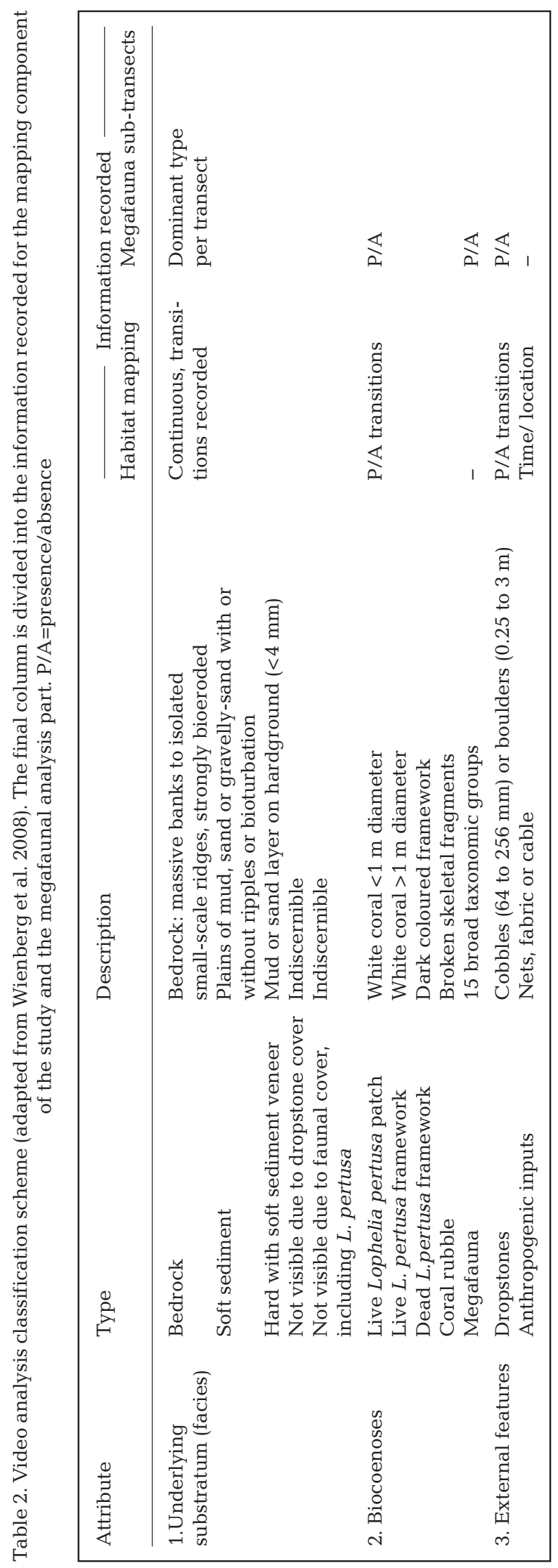


Table 3. Habitat codes assigned to sub-transects according to facies-biocoenoses combination. Substrate: $\mathrm{H}=$ hard, B = bioturbated, $\mathrm{S}=$ soft. C: cobbles or boulders, R: coral rubble, D: dead reef, L: live reef

\begin{tabular}{|lccccc|}
\hline $\begin{array}{l}\text { Habitat } \\
\text { code }\end{array}$ & Substrate & C & R & D & L \\
\hline 1. HC & Hard & $\sqrt{ }$ & & & \\
2. HCR & Hard & $\sqrt{ }$ & $\sqrt{ }$ & & \\
3. B & Bioturbated & & & & \\
4. BCR & Bioturbated & $\sqrt{ }$ & $\sqrt{ }$ & & \\
5. S & Soft & & & & \\
6. SC & Soft & $\sqrt{ }$ & & & \\
7. SCR & Soft & $\sqrt{ }$ & $\sqrt{ }$ & & \\
8. SCRD & Soft & $\sqrt{ }$ & $\sqrt{ }$ & & \\
9. SCD & Soft & & $\sqrt{ }$ & & \\
10. SRD & Soft & & $\sqrt{ }$ & $\sqrt{ }$ & \\
11. SRDL & Soft & & $\sqrt{ }$ & $\sqrt{ }$ & $\sqrt{ }$ \\
12. D & Not Visible & & & $\sqrt{ }$ & \\
13. DL & Not Visible & & & $\sqrt{ }$ & $\sqrt{ }$ \\
\hline
\end{tabular}

against the secondary axis, whereas negative correlations represent the secondary axis offset against the primary axis. Average water temperature increased during the 3 mo mooring deployment and this trend was removed with a high-pass filter before applying CCF analysis. Cyclic patterns in the temperature dataset from Banana Reef were analysed by applying spectral analysis using software package PAST 2.00, which employs an algorithm by Press et al. (1992). The frequencies on the $x$-axis of the periodogram are originally given in $1 /(x$ time unit), e.g. 0.1 equals a period of $10 \mathrm{~h}$ if unit time is hours. The $y$-axis shows the power which is proportional to the square of the amplitudes of the sinusoids present in the data.

\section{Biochemical analyses of SPM and Lophelia pertusa}

During a 2007 cruise with RV Pelagia, 2 CTD yoyos (repetitive drops of the CTD at one site) were conducted, one on the eastern ridge of Mingulay 1 (20 June, Stn 31) and another at Banana Reef (21 June, Stn 86). The locations of the yoyos were similar to the longterm moorings (Fig. 2). Both CTD yoyos covered the flood and subsequent ebb of a tidal cycle (total durations were $\sim 13 \mathrm{~h}$ ). The CTD system was a Seabird 911 CTD mounted on a rosette sampler with 22 NOEX bottles each of 121 . Water samples from the surface $(n=5)$ and from $5 \mathrm{~m}$ above bottom $(\mathrm{n}=14)$ were collected at each reef and were filtered directly on GFF filters for the analysis of SPM. A video-guided grab was used to collect samples of live coral on both reefs for analysis of their stable isotope signatures and lipid contents. Additionally, hauls were made with a $300 \mu \mathrm{m}$ plankton net to collect pelagic copepods for stable isotope analysis.

Phytopigments in the SPM samples were analysed on a Waters HPLC system coupled to a Photodiode array and fluorometer. For details on the methodology see Duineveld et al. (2004). The $\delta^{13} \mathrm{C}$ signatures of SPM and coral tissue samples were measured using a Thermofinnigan Delta Plus isotope ratio mass spectrometer (IRMS) connected online to a Carlo Erba Instruments Flash 1112 elemental analyzer. Samples were analyzed following de-carbonation overnight with $1 \mathrm{M} \mathrm{HCl}$ for SPM and $4 \mathrm{M} \mathrm{HCl}$ for Lophelia pertusa and were neutralised by repetitive washing with distilled water and subsequently lyophilised prior to analysis. The $\delta^{15} \mathrm{~N}$ signatures of SPM coral tissue were measured directly, i.e. with no prior treatment, on separate filters and tissue aliquots by Iso-Analytical (Crewe, UK) using a Europa 20-20 IRMS. An internal fish standard was analysed by both IRMS and precision was better than $0.1 \%$. Lipid extractions of SPM were carried out on lyophilised filters and on lyophilised $L$. pertusa polyps from the Banana ( $\mathrm{n}=5$, June 2007) and Mingulay 1 reefs ( $=$ 5 , July 2006). The methods are described in full in Jeffreys et al. (2009). Lipids were normalised to the amount of water filtered in SPM samples, and to the dry weight (DW) of $L$. pertusa polyps. Diagnostic lipid indices (Table 4) were used to assess SPM quality and the trophic preferences of $L$. pertusa.

In order to compare stable isotope values and diagnostic lipid and pigment indices of SPM between reefs (Mingulay 1, 20 June and Banana Reef, 21 June) and between surface and bottom SPM, 1-way analyses of variance (ANOVA) were performed to ascertain statistical differences, providing data met assumptions of normality and homogeneity of variance. If the data did not meet the assumptions, a Kruskal-Wallis test or Mann-Whitney $U$-test was performed. All statistical tests were conducted using SYSTAT 12.0 software.

Differences between groups of SPM and Lophelia pertusa tissue samples from the 2 reefs with respect to lipid concentrations as well as diagnostic indices (Table 4), were explored by multivariate analysis of similarities (ANOSIM) using PRIMER 6. For this analysis, Euclidean distance similarity matrices were calculated with fourth root transformed values. The contribution of variables (lipid, index) to the total dissimilarity between groups was determined using SIMPER. 
Table 4. Diagnostic lipid indices. SPM: suspended particulate matter, PUFA: polyunsaturated fatty acids, and MUFA: monounsaturated fatty acids

\begin{tabular}{|c|c|c|}
\hline Index & Indicator for & Reference \\
\hline Unsaturated:saturated fatty acids & $\begin{array}{l}\text { Lability of organic fraction of SPM. } \\
\text { Unsaturated fatty acids are more labile } \\
\text { than saturated fatty acids. }\end{array}$ & $\begin{array}{l}\text { Hayakawa et al. (1997) } \\
\text { Kiriakoulakis et al. (2004) }\end{array}$ \\
\hline PUFA:MUFA & $\begin{array}{l}\text { Lability of organic fraction of SPM. } \\
\text { PUFAs are more labile than MUFAs. }\end{array}$ & Kiriakoulakis et al. (2005) \\
\hline $\begin{array}{l}\text { Phytoplankton index: } \mathrm{C}_{20: 5(\mathrm{n}-3)}+\mathrm{C}_{22: 6(\mathrm{n}-3)} \\
\text { as \% total lipids }\end{array}$ & $\begin{array}{l}\text { Lability of organic fraction of SPM and the } \\
\text { contribution of phytoplankton to lipid pool. } \\
\mathrm{C}_{20: 5(\mathrm{n}-3)} \text { and } \mathrm{C}_{22: 6(\mathrm{n}-3)} \text { are indicative of diatoms } \\
\text { and dinoflagellates. }\end{array}$ & Harwood \& Russell (1984) \\
\hline $\begin{array}{l}\text { Zooplankton index: } \mathrm{C}_{20: 1}, \mathrm{C}_{22: 1}, \mathrm{C}_{24: 1} \\
\text { fatty acids \& alcohols as \% total lipids }\end{array}$ & $\begin{array}{l}\text { The proportion of zooplankton available in SPM } \\
\text { and in the diet of Lophelia pertusa. }\end{array}$ & Dalsgaard et al. (2003) \\
\hline $\begin{array}{l}\text { Bacterial index: odd numbered } \\
\text { saturated and branched FA \& } \mathrm{C}_{18: 1(\mathrm{n}-7)} \\
\text { as \% total lipids }\end{array}$ & $\begin{array}{l}\text { The contribution of bacteria to the diet of } \\
L \text {. pertusa and the proportion of bacteria in SPM } \\
\text { to be assessed. }\end{array}$ & $\begin{array}{l}\text { Volkman \& Johns (1977) } \\
\text { Gillan \& Johns (1986) }\end{array}$ \\
\hline $\mathrm{C}_{18: 1(\mathrm{n}-9)}: \mathrm{C}_{18: 1(\mathrm{n}-7)}$ fatty acid index & $\begin{array}{l}\text { 1. Bacteria. } C_{18: 1(n-7)} \text { is obtained from bacteria } \\
\text { or synthesised from } C_{16: 1(n-7)} \text {, which is of } \\
\text { bacterial/algal origin. } \\
\text { 2. In animal tissues } C_{18: 1(n-9)} \text { is indicative of } \\
\text { carnivory. }\end{array}$ & $\begin{array}{l}{ }^{1} \text { Volkman \& Johns (1977) } \\
{ }^{2} \text { Sargent (1976) } \\
{ }^{2} \text { Graeve et al. (1997) }\end{array}$ \\
\hline $\mathrm{C}_{22: 6}: \mathrm{C}_{20: 5}$ fatty acid index & $\begin{array}{l}\text { The relative contribution of dinoflagellates } \\
\text { to diatoms in the initial food source. }\end{array}$ & Kiriakoulakis et al. (2005) \\
\hline $\mathrm{C}_{37: 2}$ long chain alkenones & $\begin{array}{l}\text { Haptophyte algae, primarily the coccolithophorids } \\
\text { Emiliania huxleyi and Gephyrocapsa oceanica. }\end{array}$ & Conte et al. 1994 \\
\hline
\end{tabular}

\section{RESULTS}

\section{Video surveys}

The Mingulay 1 area is characterised by 2 shallow ( 100 m depth) ridges running east-west and separated by a narrow gap (Fig. 2). Video transects D and E crossed the gap separating the eastern and western ridge with depths varying between 120 to $150 \mathrm{~m}$ (Fig. 2). The facies on both transects largely consisted of soft sediment with small areas of exposed rock. Though coral rubble was prevalent along the major part of transects D and E, numerous living patches of Lophelia pertusa were observed as well. Video transects $\mathrm{F}$ and $\mathrm{G}$ closely followed the eastern ridge of Mingulay 1 at a depth of 100 to $150 \mathrm{~m}$. On both transects the main facies were soft sediments with occasional bare rock. Living coral was observed on both transects whilst dead framework was extensive along transect G. Isolated patches of live coral were observed towards both ends of transect $F$ where the occurrence of living framework was also relatively high. Coral rubble was prevalent on both sets of video footage. Other facies found along transect $F$ included cobbles and boulders. Video transect $\mathrm{H}$ (Fig. 2) closely followed the western ridge of Mingu- lay 1 and traversed a depth range of 90 to $125 \mathrm{~m}$. The substratum was mostly bare rock with cobbles and boulders but areas of soft sediment and coral rubble were also seen. No living or dead coral framework was seen along the transect.

Banana Reef forms a $2.5 \mathrm{~km}$ long ridge with an eastwest orientation and an average depth of $\sim 150 \mathrm{~m}$. The reef top protrudes $\sim 90$ to $100 \mathrm{~m}$ from the surrounding sea floor. Video transects A and B closely followed the crest of Banana Reef (Fig. 2). The bathymetry along both the video transects varied between depths of 130 to $180 \mathrm{~m}$. Where the view of the seafloor was not taken up by coral framework, silty soft substrata were observed. Dead coral framework was seen on both transects, especially on transect B. Living coral framework formed extensive dense outcrops in many parts, particularly along transect B towards the eastward end of the survey track. In some places the framework had a prominent 3D structure and the camera had to be lifted to prevent collision with tall Lophelia pertusa colonies. Besides the extensive framework there were also several occurrences of isolated living coral thickets $(<1 \mathrm{~m}$ diameter $)$ along the video transect. Coral rubble was observed along the majority of sub-transects on both video tracks. Cobbles and boulders were sparse and only observed on 1 part of transect B. 
To illustrate the different settings of Mingulay 1 and Banana reefs, we selected 3 transects on Mingulay 1 (G, E, H; Fig. 2) that formed a more or less continuous line across the crest of the reef and 1 transect (B) on Banana Reef, and we counted the frequency of occurrence of different habitats along these transects in 25 m sections (Table 3). Banana Reef had a distinctly higher proportion of habitats dominated by live and dead Lophelia pertusa framework (Fig. 3). Furthermore, in absolute terms Banana Reef appears to have more living coral when the track lengths with living coral along the video transects are cumulated. The total length of live framework on Banana Reef was twice that observed on Mingulay 1, with 550 m compared to $275 \mathrm{~m}$. Coral cover expressed as percentage of reef length was also considerably higher on Banana Reef, $24 \%$ versus $5 \%$ on Mingulay 1.

A total of 14 broad taxonomic groups of megafauna could be distinguished from all video footage analysed. Cluster analyses of the counts within the $25 \mathrm{~m}$ sub-transects showed a distinction between megafauna on Banana Reef and Mingulay 1. This is illustrated by the MDS plot in Fig. 4. An ANOSIM analysis of the 2 groups of samples revealed a significant difference in the assemblage on the reefs $(R=0.21, \mathrm{p}<$ 0.001). SIMPER analysis revealed that stony corals (Lophelia pertusa), galatheid crabs and encrusting as well as branched sponges were the groups that contributed to the dissimilarity between the 2 reefs. While L. pertusa was more abundant on Banana Reef, galatheid crabs and (erect and encrusting) sponges were more common on Mingulay 1 Reef. When corals were excluded from the analysis, ANOSIM analysis revealed a significant difference between the 2 reefs $(\mathrm{R}=0.141, \mathrm{p}<0.001)$. In this case distinction was driven by galatheid crabs and sponges on Mingulay 1 Reef, and starfish on Banana Reef.

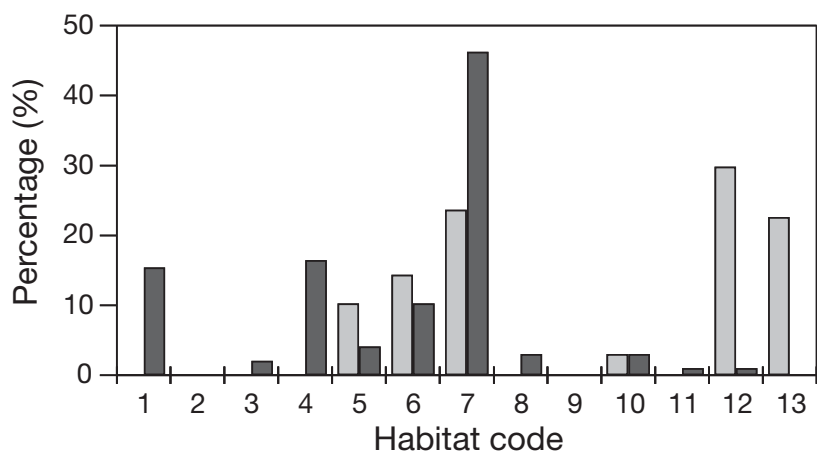

Fig. 3. Percentage of occurrence for the different habitat types (cf. Table 3 ) along transects crossing Mingulay 1 (G, E, $\mathrm{H})$ and Banana Reef (B). Dark bars = Mingulay 1 Reef transects; light bars = Banana Reef transect

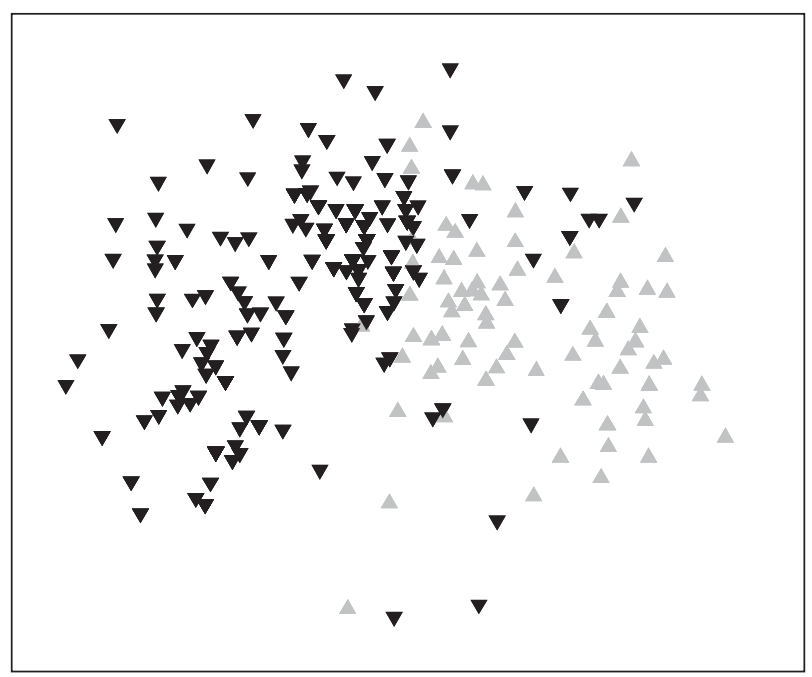

Fig. 4. MDS plot of megafauna presence-absence along Mingulay 1 Reef (black) and Banana Reef (gray). Each symbol represents video observations along $25 \mathrm{~m}$ sub-transect length. The resemblance matrix is based on Euclidean distance. The stress of the MDS configuration is 0.16

\section{Hydrography}

The mooring deployed at Mingulay 1 showed a tidal downwelling generated by a hydraulic jump caused by the reef itself forming a barrier in the tidal currents. Details of the downwelling process are given in Davies et al. (2009). Below we report only data relevant for the comparison with Banana Reef. Maximum spring tide current speeds at Mingulay 1 were $\sim 40 \mathrm{~cm} \mathrm{~s}^{-1}$ (Fig. 5A). The downwelling was visible on the instrument records as concurring peaks of temperature and fluorescence at the onset of ebb tide (Fig. 5B). This sequence of events was demonstrated by Davies et al. (2009) using CCF analyses, which yielded a negative correlation between current speed and temperature (and fluorescence) with a lag of $1 \mathrm{~h}$ representing the delay between the slack tide (minimal current) and temperature peak.

The records from Banana Reef showed a higher mean current speed than at Mingulay 1 with spring tide maxima of $\sim 65 \mathrm{~cm} \mathrm{~s}^{-1}$ (see Fig. 5C) and a distinct diurnal tidal cycle (Fig. 5D). The predominant current directions were SSW and NNE with a residual direction to NNE. Measurements from Banana Reef displayed concurring temperature and fluorescence peaks (Fig. 5D). These resembled the pattern observed at Mingulay 1 (Fig. 5B) with strong $\sim 12 \mathrm{~h}$ and weaker $\sim 6$ h cycles, as shown by spectral analysis of the temperature record (Fig. 6). Highest peaks of temperature (and fluorescence) at Banana Reef 

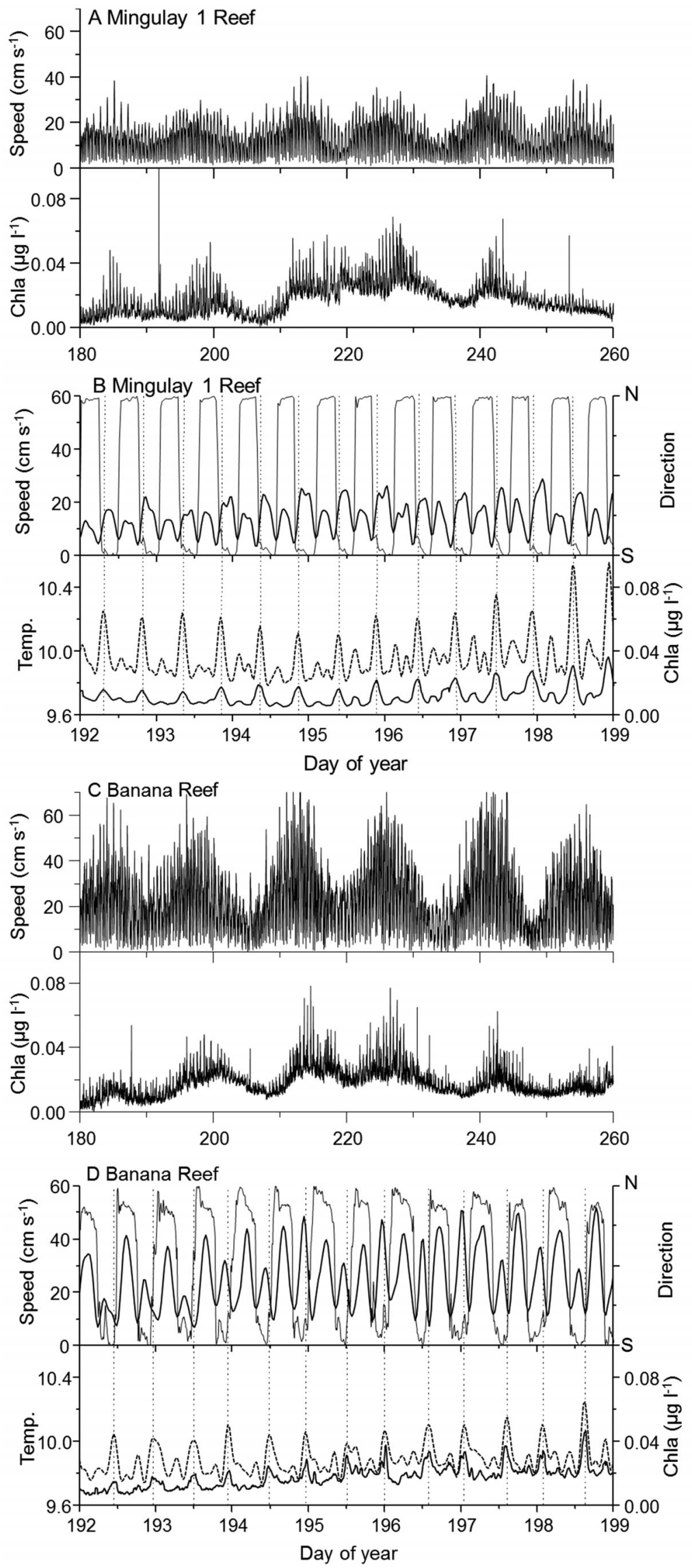

occurred in the second half of the ebb tide, $\sim 4.5 \mathrm{~h}$ after the reversal from flood to ebb and $1 \mathrm{~h}$ before the reversal from ebb to flood. The different timing of temperature peaks at the 2 reefs in relation to the tidal direction reversal is illustrated in Fig. 7 by means of crosscorrelation function (CCF) plots depicting the correlation between temperature and current direction changes. At Mingulay 1, major temperature peaks follow a flood to ebb current reversal (negative) with a lag of $1 \mathrm{~h}$ (Fig. 7A). By contrast, at Banana Reef this lag has extended to $4.5 \mathrm{~h}$ after the local reversal from flood to ebb (Fig. 7B). These outcomes match with the time lag in the correlation between temperature records from both reefs which amounts to $\sim 3.5 \mathrm{~h}$ (Fig. 7C).

\section{Stable isotope analyses of SPM and Lophelia pertusa}

Results (mean $\pm \mathrm{SD}$ ) of the stable isotope analysis of the organic fraction of SPM are summarised in Table 5, which also shows outcomes of Mann-Whitney $U$-tests. The $\delta^{13} \mathrm{C}$ values of surface SPM at Mingulay 1 and Banana Reef were in a narrow range between -23.0 and $-21.2 \%$. Bottom SPM $\delta^{13} \mathrm{C}$ values ranged between -20.2 and $-14.6 \%$. At both Mingulay 1 and Banana Reef, bottom SPM was significantly more enriched in ${ }^{13} \mathrm{C}$ than surface SPM. Moreover, bottom SPM at Banana Reef was significantly enriched in ${ }^{13} \mathrm{C}$ compared to Mingulay 1.

Surface SPM $\delta^{15} \mathrm{~N}$ values at both reefs ranged from 5.5 to $6.2 \%$, and surface SPM from Banana Reef was slightly but

Fig. 5. Three month records of near-bottom current speed and fluorescence $(\mathrm{A}, \mathrm{C})$ and 7 day excerpts $(B, D)$ from Mingulay 1 and Banana reefs, respectively. The excerpts cover the period 12 to 19 July 2007. Current direction (thin line) in B,D is expressed as the cosine to focus on the north and south component. The temperature record in $B, D$ is dashed. The dotted vertical lines in B,D mark major temperature peaks for comparison with the tidal cycle 


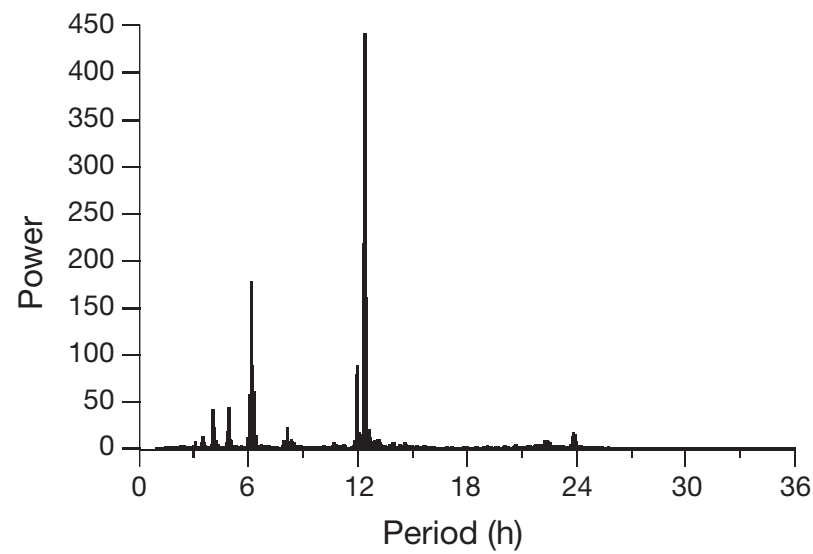

Fig. 6. Spectral analysis of the 3 mo temperature record from Banana Reef showing tidal periodicity of $\sim 6$ and $12 \mathrm{~h}$. The $\mathrm{x}$-axis values have been converted to periods
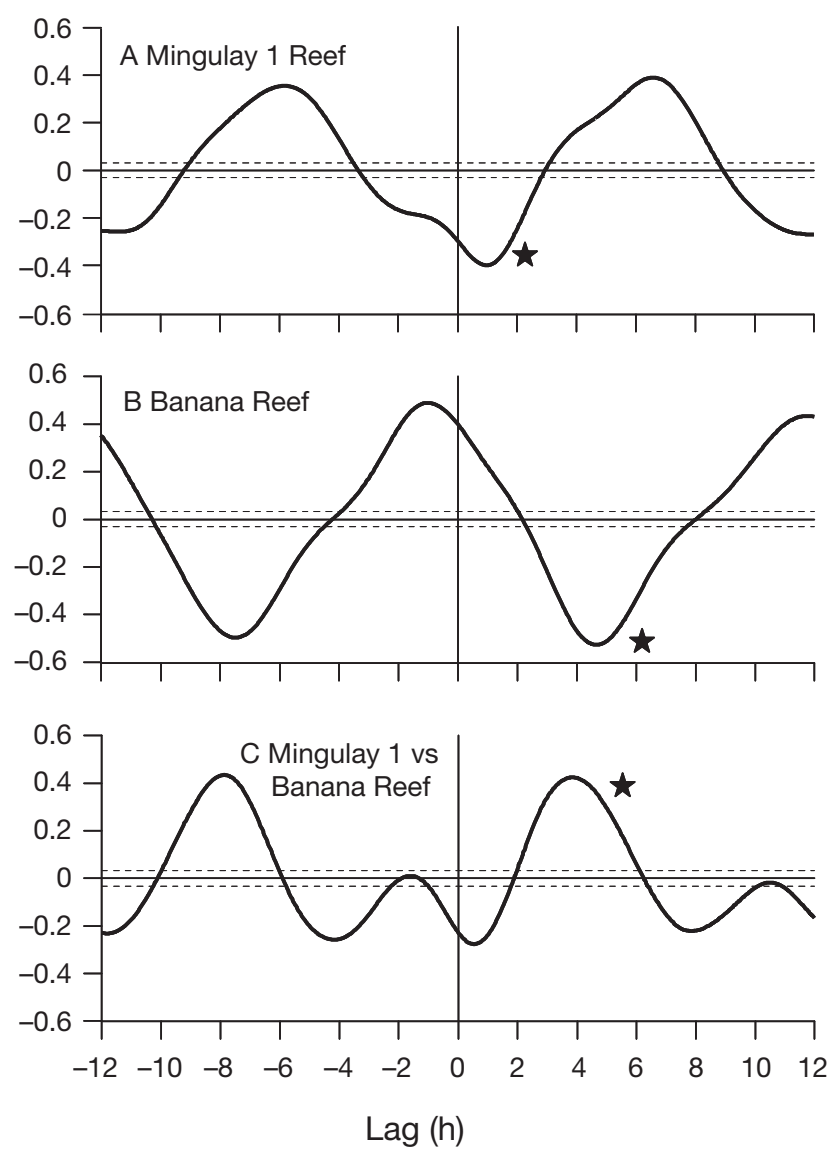

Fig. 7. Plots showing results of cross-correlation analysis with time lags between -12 and $12 \mathrm{~h}$. The y-axis represents the correlation coefficient. Relevant peaks have been marked with $\star$. (A) Mingulay 1 Reef, lag $+1 \mathrm{~h}$ between current reversal (north-to-south is negative) and temperature peak. (B) Banana Reef, lag $+4.5 \mathrm{~h}$ between current reversal (north-tosouth negative) and temperature peak. (C) Mingulay 1 and

Banana Reef: lag $3.5 \mathrm{~h}$ between peaks in temperature significantly depleted in ${ }^{15} \mathrm{~N}$ compared to Mingulay 1 with mean values of 5.5 and $5.9 \%$, respectively. Samples of bottom SPM had $\delta^{15} \mathrm{~N}$ values ranging from 4.3 to $8.3 \%$. At both reefs bottom SPM was significantly enriched in ${ }^{15} \mathrm{~N}$ compared to corresponding surface samples (Table 5).

Tissues of Lophelia pertusa from Mingulay 1 had $\delta^{13} \mathrm{C}$ values varying between -20.5 and $-21.0 \%$ and $\delta^{15} \mathrm{~N}$ between 7.9 and $9.5 \%$ (Table 5). Corresponding ranges in corals from Banana Reef were -20.0 to $-21.0 \%$ for $\delta^{13} \mathrm{C}$, and 8.1 to $9.7 \%$ for $\delta^{15} \mathrm{~N}$. The stable isotopic signatures did not differ between reefs (Table 5), and are in agreement with those of previous studies (Duineveld et al. 2007, Carlier et al. 2009). Pelagic copepods that were collected over Mingulay 1 Reef had $\delta^{13} \mathrm{C}$ values between -21.9 to $-22.4 \%$ and $\delta^{15} \mathrm{~N}$ values between 6.9 and $7.7 \%$.

\section{Lipids in SPM}

Lipid distributions in the organic fraction of SPM samples were complex and dominated by fatty acids (both saturated and unsaturated) accounting for $>72 \%$ of the total lipids in all SPM samples. At both reefs, fatty acids (FA) ranged from $\mathrm{C}_{14}$ to $\mathrm{C}_{26}$, with the dominant saturated fatty acids (SFAs) being $\mathrm{C}_{14}, \mathrm{C}_{16}$ and $\mathrm{C}_{18}$. FAs were the most abundant lipid class in the samples from Mingulay 1. Branched fatty acids (BRFAs) were a minor constituent of the total lipids $(<1.5 \%)$ and were represented by both $\mathrm{C}_{15}$ isomers and by the iso- $\mathrm{C}_{16}$ acid. Mono-unsaturated fatty acids (MUFAs) were dominated by the $\mathrm{C}_{16: 1(\mathrm{n}-9)}, \mathrm{C}_{16: 1(\mathrm{n}-7)}$, $\mathrm{C}_{18: 1(\mathrm{n}-9)}$ and $\mathrm{C}_{18: 1(\mathrm{n}-7)}$ homologues. Polyunsaturated fatty acids (PUFAs) distributions were dominated by $\mathrm{C}_{18: 2(\mathrm{n}-6)}, \mathrm{C}_{18: 4(\mathrm{n}-3)}, \mathrm{C}_{20: 5(\mathrm{n}-3)}$ and $\mathrm{C}_{22: 6(\mathrm{n}-3)} \cdot \mathrm{n}$-Alcohols contributed $<11 \%$ to the total lipid pool and included $\mathrm{C}_{14}$ to $\mathrm{C}_{24}$ homologues in addition to the mono-unsaturated alcohols $\mathrm{C}_{20: 11}, \mathrm{C}_{22: 1}$ and $\mathrm{C}_{24: 1}$. Sterols generally contributed $\leq 5 \%$ of the total lipids. The most abundant sterols included: $\mathrm{C}_{27} \Delta^{5,22}, \mathrm{C}_{27} \Delta^{5}$ and $\mathrm{C}_{28} \Delta^{5,22}$. The long chain alkenone $\mathrm{C}_{37: 2}$ constituted $<1.5 \%$ of the total lipids. Hydroxy acids were present in trace amounts at $<0.5 \%$. Prior to analyzing differences in lipid composition between SPM samples, individual lipids were grouped into principal classes, i.e. SFAs, BRFAs, MUFAs, PUFAs, sterols, alcohols, hydroxy acids and long chain ketones. Concentrations were normalized to volume water as proxy for the overall food availability and to organic carbon as proxy for the quality of ingested particles. Differences between groups of SPM samples in terms of lipid classes were analysed with ANOSIM and SIMPER. 
Table 5. Levels of $\delta^{13} \mathrm{C}$ and $\delta^{15} \mathrm{~N}$ (values in \%, mean $\pm \mathrm{SD}$ ) for surpended particulate matter (SPM) and Lophelia pertusa tissue including outputs of MannWhitney $U$-tests (MWU). ns: not significant; ${ }^{*},{ }^{* *}$ : significantly different at $\mathrm{p}<$ 0.05 or $\mathrm{p}<0.01$, respectively. N: replicates

\begin{tabular}{|lccccr|}
\hline & Isotope & $\begin{array}{c}\text { Mingulay } \\
1 \text { Reef }\end{array}$ & $\begin{array}{c}\text { Banana } \\
\text { Reef }\end{array}$ & MWU & N \\
\hline Surface SPM & $\delta^{13} \mathrm{C}$ & $-22.2 \pm 2.1$ & $-21.7 \pm 0.5$ & $\mathrm{~ns}$ & 5 \\
Bottom SPM & $\delta^{13} \mathrm{C}$ & $-17.6 \pm 1.5$ & $-15.9 \pm 0.9$ & ${ }^{* *}$ & 14 \\
MWU & & $*^{* *}$ & ${ }^{* *}$ & & \\
Surface SPM & $\delta^{15} \mathrm{~N}$ & $5.9 \pm 0.1$ & $5.5 \pm 0.5$ & $* *$ & 5 \\
$\begin{array}{l}\text { Bottom SPM } \\
\text { MWU }\end{array}$ & $\delta^{15} \mathrm{~N}$ & $6.6 \pm 0.9$ & $6.5 \pm 0.9$ & $\mathrm{~ns}$ & 14 \\
$\begin{array}{l}\text { L. pertusa } \\
\text { tissue }\end{array}$ & $\delta^{13} \mathrm{C}$ & $-20.3 \pm 0.3$ & $-20.5 \pm 0.4$ & $\mathrm{~ns}$ & 5 \\
& $\delta^{15} \mathrm{~N}$ & $8.7 \pm 1.1$ & $9.0 \pm 0.7$ & $\mathrm{~ns}$ & 5 \\
\hline
\end{tabular}

Additionally, samples were compared with respect to diagnostic lipid indices presented in Table 4.

Between-reef differences in total lipid concentrations were not significant irrespective of concentrations being normalised to volume or organic carbon (Mann-Whitney $U$-test, $\mathrm{p}>0.05$ ). A between-reef comparison of the lipid class composition $\left(\mu \mathrm{g} \mathrm{l}^{-1}\right)$
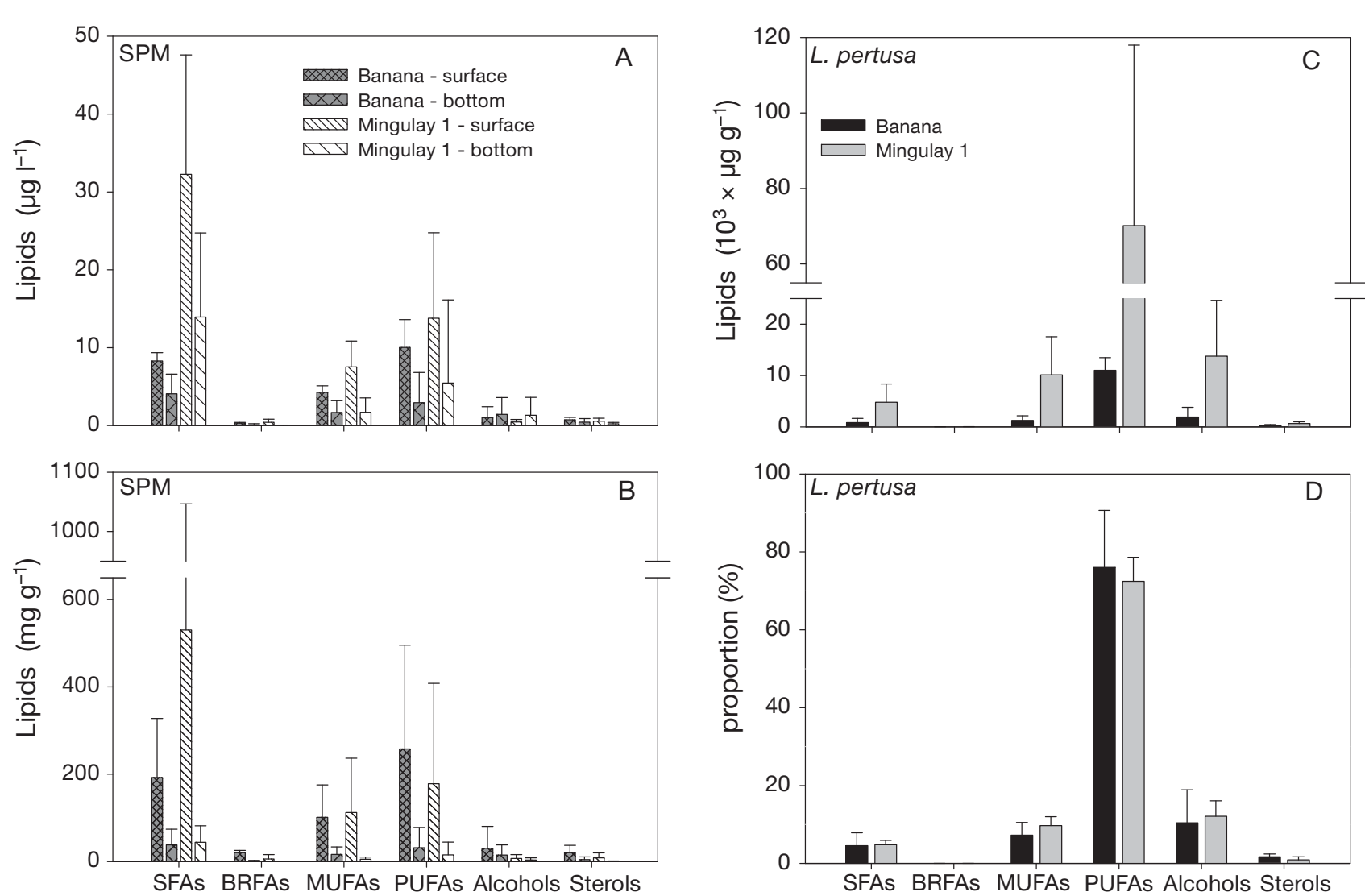

in the surface and bottom SPM showed that only bottom samples differed (ANOSIM, R $=0.238, \mathrm{p}=$ 0.002). The difference was for most part due to a higher concentration of PUFAs at Banana Reef. The same results were obtained with lipid classes normalised to organic carbon (ANOSIM, R = 0.155, $\mathrm{p}=0.011$ ). A formal test between the PUFA concentrations $\left(\mu \mathrm{g} \mathrm{l}^{-1}\right)$ in bottom SPM from the 2 reefs showed a significant difference (Mann-Whitney U-test, p $=0.011$ ). The lipid class composition of surface and bottom samples is illustrated in Fig. 8A,B with concentrations normalised to volume and organic carbon.

Within reefs, total lipid concentrations $\left(\mu \mathrm{g} \mathrm{l}^{-1}\right)$ were significantly higher at the surface at both Banana and Mingulay 1 reefs (Mann-Whitney $U$-tests, p < 0.012 and 0.026 , respectively). According to ANOSIM, the lipid class composition in surface and

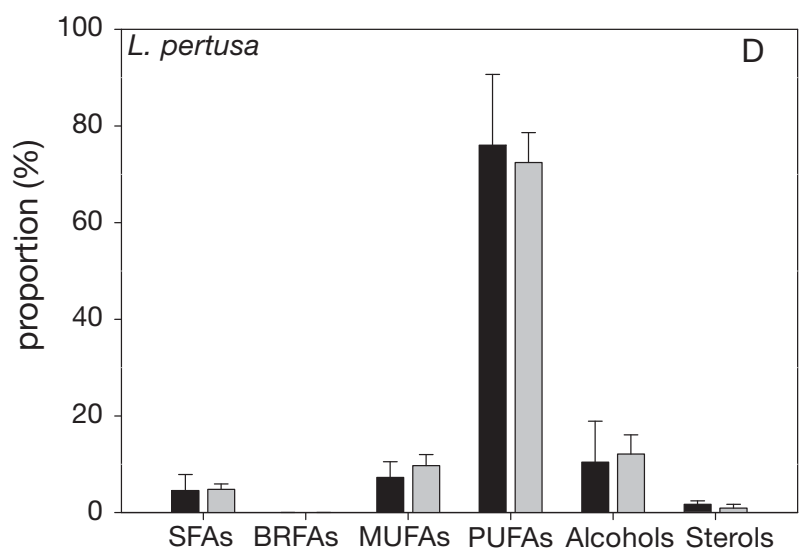

Fig. 8. Quantities of principal lipid classes in $(A, B)$ the organic fraction of suspended particulate matter $(S P M)$ and $(C, D)$ in Lophelia pertusa tissue. Values are expressed in (A) $\mu \mathrm{g}$ lipids per 1 of filtered water, (B) mg lipids per g of organic carbon, (C) $\mu \mathrm{g}$ per $\mathrm{g}$ dry weight of tissue, and (D) as a proportion of the lipid pool in the tissue. Means $\pm 1 \mathrm{SD}$ with $\mathrm{n}=5, \mathrm{n}=14$, and $\mathrm{n}=5$ for surface, bottom SPM, and L. pertusa, respectively. Abbreviations for lipid classes are given in the text 
Table 6. Results of SIMPER analyses of the dissimilarity between SPM samples with respect to their lipid class composition. The \% contribution by each class to the dissimilarity is listed in the last column. Means are based on fourth root transformed concentrations $\left(\mu \mathrm{g} \mathrm{l}^{-1}\right)$ PUFAs: polyunsaturated fatty acids; MUFAs: monounsaturated fatty acids; BRFAs: branched fatty acids; SFAs: saturated fatty acids

\begin{tabular}{|c|c|c|c|}
\hline \multirow[t]{2}{*}{ Lipid class } & \multicolumn{2}{|c|}{ Mean concentration } & \multirow{2}{*}{$\begin{array}{c}\% \\
\text { Contrib }\end{array}$} \\
\hline & Bottom & Surface & \\
\hline \multicolumn{4}{|l|}{ Mingulay 1 Reef } \\
\hline PUFAs & 4.45 & 9.93 & 46.52 \\
\hline SFAs & 10.2 & 13.00 & 13.11 \\
\hline BRFAs & 0.25 & 3.08 & 12.22 \\
\hline MUFAs & 5.83 & 9.17 & 11.72 \\
\hline Long chain ketones & 0.0 & 2.46 & 8.21 \\
\hline \multicolumn{4}{|l|}{ Banana Reef } \\
\hline PUFAs & 6.35 & 9.91 & 28.08 \\
\hline Long chain ketones & 0 & 2.89 & 22.11 \\
\hline BRFAs & 1.45 & 4.19 & 16.82 \\
\hline MUFAs & 5.98 & 8.05 & 9.51 \\
\hline Alcohols & 5.31 & 5.0 & 7.91 \\
\hline SFAs & 7.77 & 9.53 & 6.70 \\
\hline
\end{tabular}

bottom water differed at both Banana Reef $(\mathrm{R}=$ $0.624, \mathrm{p}=0.001)$ and Mingulay 1 Reef $(\mathrm{R}=0.37, \mathrm{p}=$ 0.012). SIMPER analysis showed that this was primarily due to higher concentrations of PUFAs, long chain ketones and SFAs at the surface (Table 6). Again similar results were obtained when lipids were normalised to organic carbon.

Averages values of the diagnostic lipid indices in surface and bottom SPM samples are depicted in Fig. 9. Differences between samples with respect to their indices were explored with the ANOSIM and SIMPER combination after fourth root transformation and normalisation of the original values. ANOSIM demonstrated significant between-reef differences in SPM in surface $(R=0.388, p=0.008)$ and bottom $(R=$ $0.401, p=0.002)$ samples. The dissimilarity between reefs was explained by higher values of the unsaturated:saturated $\mathrm{FA}, \mathrm{C}_{22: 6}: \mathrm{C}_{20: 5}$, bacterial, phytoplankton and zooplankton lipid indices in all Banana Reef samples and a lower value of the $\mathrm{C}_{18: 1(\mathrm{n}-9)}: \mathrm{C}_{18: 1(\mathrm{n}-7)}$ in bottom SPM at Banana Reef (Table 7). There were no significant differences in diagnostic lipid indices of SPM within reefs.

\section{Lipids in Lophelia pertusa tissue}

Total quantifiable lipid concentrations in Lophelia pertusa, relative to both tissue dry weight and organic carbon, were higher at Mingulay 1 compared to Ba- nana Reef (Mann-Whitney $U$-test, $\mathrm{p}<0.05$ ). Lipid profiles were dominated by FAs, which accounted for $>85 \%$. The SFAs included: $\mathrm{C}_{14}, \mathrm{C}_{16}, \mathrm{C}_{20}$. BRFAs were a minor constituent of the total lipids $(<0.5 \%)$ in $L$. pertusa at both reefs. MUFAs included the $\mathrm{C}_{16: 1}, \mathrm{C}_{18: 1}$, $\mathrm{C}_{20: 1}$ and $\mathrm{C}_{22: 1}$ homologues. PUFAs accounted for the highest proportion of the lipids (Fig. 8C,D) and distributions were dominated by $\mathrm{C}_{20: 5(\mathrm{n}-3)}$ and $\mathrm{C}_{22: 6(\mathrm{n}-3)}$. $n$ Alcohols constituted the next important compound class and included the $\mathrm{C}_{14}$ to $\mathrm{C}_{20}$ homologues in addition to the mono-unsaturated alcohols $\mathrm{C}_{16: 1}, \mathrm{C}_{18: 1}$, $\mathrm{C}_{20: 1}, \mathrm{C}_{22: 1}$ and $\mathrm{C}_{24: 1}$. Sterols generally contributed $\leq 2 \%$ of the total lipid at both reefs, the most abundant sterol being cholesterol, $\mathrm{C}_{27} \Delta^{5}$ (Fig. $8 \mathrm{C}, \mathrm{D}$ ).

As with SPM samples, between-reef differences in the lipid class composition of Lophelia pertusa were explored with ANOSIM analyses. Lipid composition of $L$. pertusa differed $(\mathrm{R}=0.404, \mathrm{p}=0.032)$ between reefs when concentrations were expressed as $\mu \mathrm{g} \mathrm{g}^{-1}$ of tissue DW (Fig. 8C). The same result was obtained with lipid concentrations expressed relative to organic carbon. The distinction between tissue samples was according to the SIMPER analysis mainly due to PUFAs and monounsaturated alcohols with contributions of $\sim 37$ and $\sim 26 \%$, respectively. When lipid concentrations were expressed in proportions of the lipid pool, no significant difference was found between $L$. pertusa from the 2 reefs $(\mathrm{R}=0.112, \mathrm{p}=$ 0.175 ; Fig. 8D). No significant differences were observed between $L$. pertusa from the 2 reefs with respect to the diagnostic lipid indices (ANOSIM R = 0.248, $\mathrm{p}=0.056$; Fig. 9).

\section{Pigment analyses of SPM}

The concentrations of main phytopigments observed in SPM samples taken from both Banana Reef and Mingulay 1 are listed in Table 8. Within both reefs, phytopigment distributions differed significantly between surface and bottom SPM samples (ANOSIM, R $=0.83, \mathrm{p}=0.001$ at Banana Reef and $\mathrm{R}=$ $0.991, p=0.001$ at Mingulay 1). SIMPER analysis showed that chl $a$ and $c_{2}$ accounted for these differences. Both pigments were present in higher concentrations in surface SPM at the 2 reefs. Surface SPM samples also had lower concentrations of total phaeopigments (phaeophorbides, phaeophytines) and correspondingly higher ratios of chl a: phaeopigments, (Mann-Whitney $U$ - test, $\mathrm{p}=0.001$ ). The latter was used as an index for the freshness of the phytodetritus (Lavaleye et al. 2002). Between-reef differences of chl a/ $/$ phaeopigments ratios in bottom 

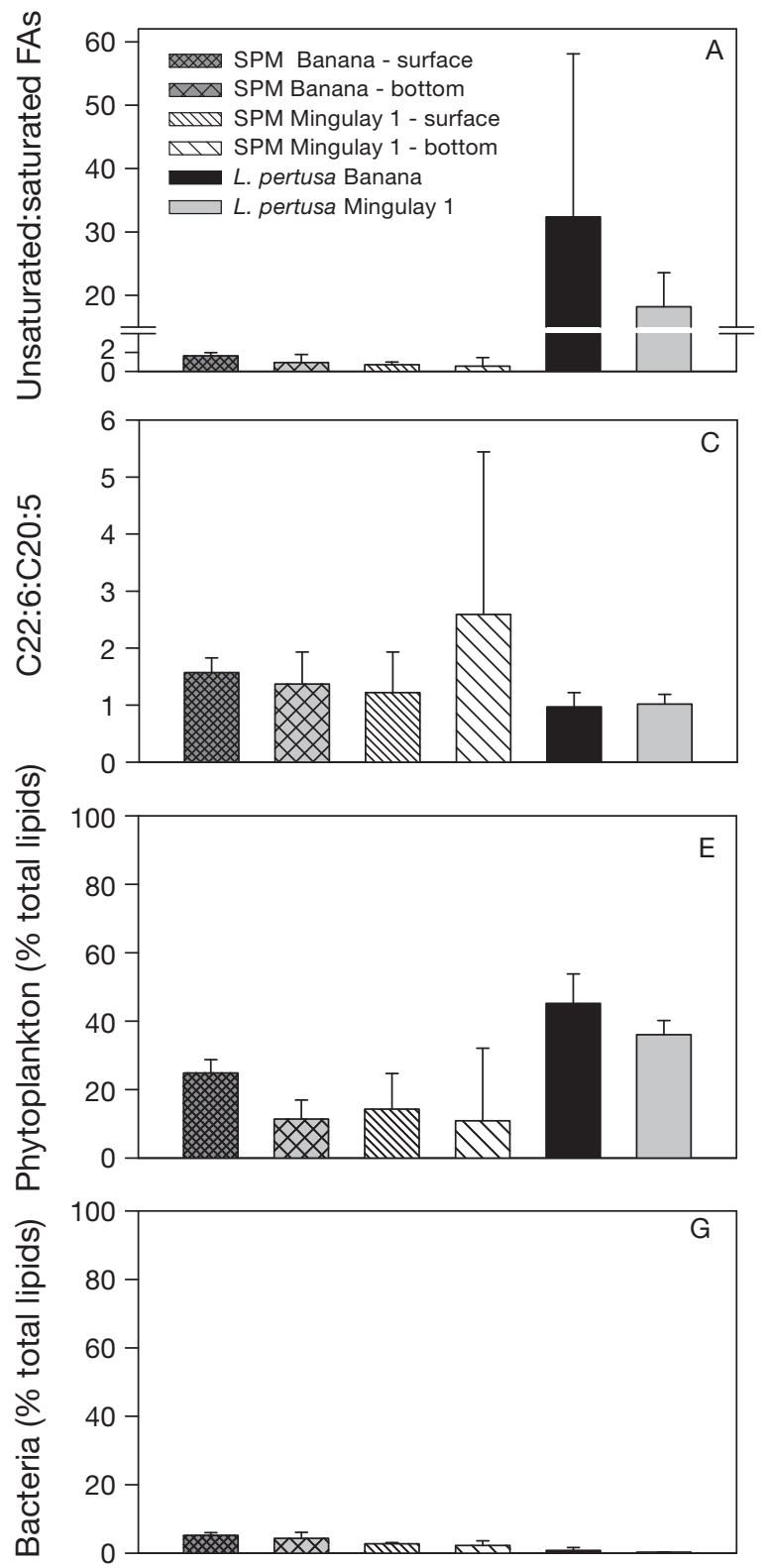

and surface water samples were not significant (Mann-Whitney $U$-test, $\mathrm{p}>0.150$ ).

\section{DISCUSSION}

The quality and quantity of food resources, i.e. the organic fraction of SPM, available to benthic ecosystems in deep water has been shown to have an important role in the structuring and functioning of the communities (Wigham et al. 2003, Witte et al. 2003, Ruhl \& Smith 2004, Ruhl 2008). CWC communities are no exception to this. Recent studies have demonstrated that fresh particulate organic matter originating from the
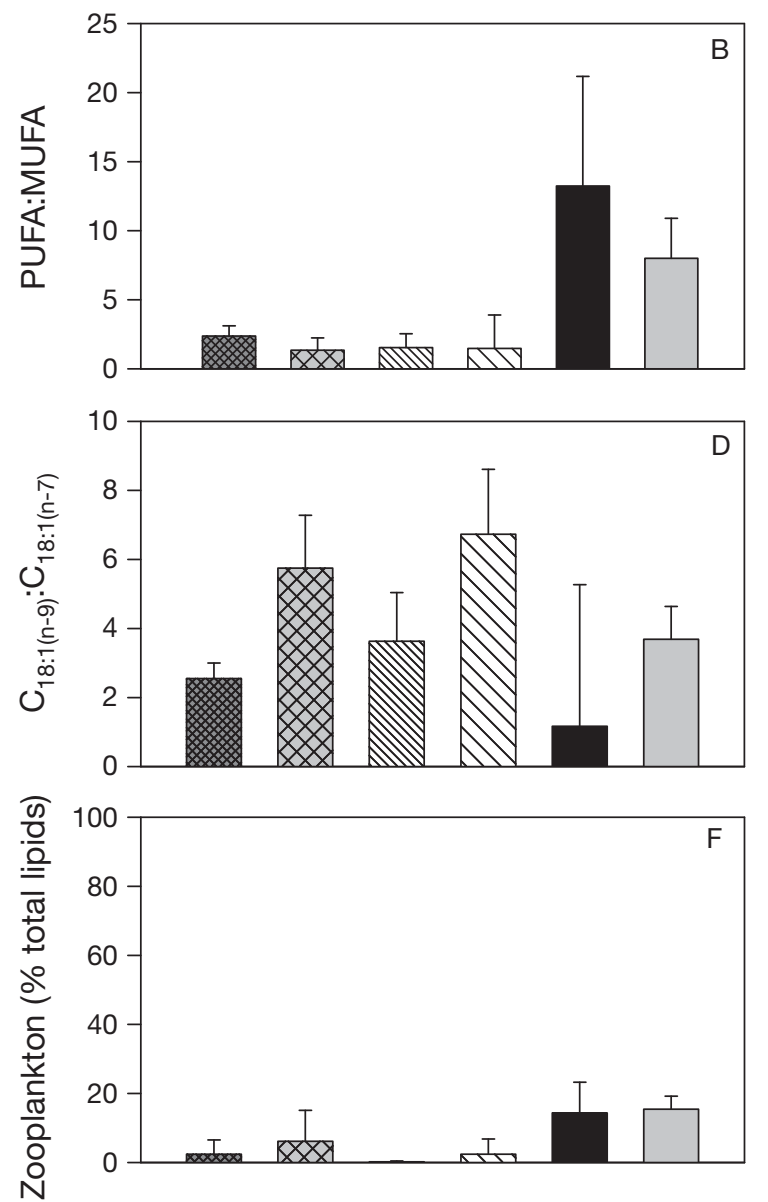

Fig. 9. Diagnostic lipid indices in the organic fraction of suspended particulate matter (SPM) and in Lophelia pertusa tissue at Banana and Mingulay 1 reefs. Means $\pm 1 \mathrm{SD}$. $\mathrm{N}=5,14$ and 5 for surface, bottom SPM and L. pertusa, respectively. See Table 4 for explanation of indices

photic zone is transported down and incorporated in communities dominated by CWCs (Duineveld et al. 2004, Kiriakoulakis et al. 2004, Duineveld et al. 2007, Carlier et al. 2009, Davies et al. 2009). The actual mechanisms advecting particulate organic matter vary from reef to reef and may involve enhanced tidal currents, Ekman transport or internal waves (White et al. 2005, Thiem et al. 2006, Mienis et al. 2007, Davies et al. 2009, White \& Dorschel 2010, Wagner et al. 2011). In most reef settings, the frameworks formed by the skeletons of Lophelia pertusa and Madrepora oculata probably play an important role by trapping advected POM in a similar way as it does with sediment (de Haas et al. 2009). 
Table 7. SIMPER analyses of the dissimilarity between suspended particulate matter (SPM) samples with respect to diagnostic lipid indices (see Table 4). The \% contribution by each index to the dissimilarity is listed in the last column. The means of the index values were calculated on the basis of normalized fourth root transformed values. Unsat FA: unsaturated fatty acids; Sat FA: saturated fatty acids; Bact FA: bacterial fatty acids; EPA: eicosapentaenoic acid; DHA: docosahexaenoic acid; PUFA: polyunsaturated fatty acids; MUFA: monounsaturated fatty acids

\begin{tabular}{|c|c|c|c|c|}
\hline \multirow[t]{2}{*}{ Lipid index } & \multirow[t]{2}{*}{ Diet indicator for } & \multicolumn{2}{|c|}{ Mean index } & \multirow{2}{*}{$\begin{array}{c}\% \\
\text { Contrib. }\end{array}$} \\
\hline & & Banana Reef & Mingulay 1 & \\
\hline \multicolumn{5}{|l|}{ Surface water SPM } \\
\hline Unsat FA:Sat FA & Lability of organic fraction of SPM & 1.030 & -0.081 & 24.56 \\
\hline $\mathrm{C}_{20: 1}$ and $\mathrm{C}_{22: 1}$ :total lipids (\%) & Zooplankton & 0.165 & -0.615 & 22.9 \\
\hline $\mathrm{C}_{22: 6}^{20.1}: \mathrm{C}_{20: 5}$ & Dinoflagellates vs. diatoms & 0.658 & 0.230 & 18.03 \\
\hline Bact FA:total lipids (\%) & Bacteria & 0.725 & -0.074 & 14.24 \\
\hline EPA \& DHA:total lipids (\%) & Phytoplankton & 0.844 & 0.362 & 11.25 \\
\hline \multicolumn{5}{|l|}{ Bottom water SPM } \\
\hline $\mathrm{C}_{20: 1}$ and $\mathrm{C}_{22: 1}$ total lipids (\%) & Zooplankton & 0.670 & -0.510 & 15.33 \\
\hline $\mathrm{C}_{18: 1(\mathrm{n}-9)}: \mathrm{C}_{18: 1(\mathrm{n}-7)}$ & Bacterial degradation & 0.350 & -0.704 & 15.04 \\
\hline Bact FA:total lipids (\%) & Bacteria & 0.401 & -0.634 & 15.03 \\
\hline $\mathrm{C}_{22: 6}: \mathrm{C}_{20: 5}$ & Dinoflagellates vs. diatoms & 0.423 & -0.74 & 14.55 \\
\hline PUFA:MUFA & Lability of organic fraction of SPM & 0.248 & -0.597 & 13.58 \\
\hline EPA \& DHA:total lipids (\%) & Phytoplankton & 0.294 & -0.724 & 13.56 \\
\hline Unsat FA:Sat FA & Lability of organic fraction of SPM & 0.274 & -0.671 & 12.90 \\
\hline
\end{tabular}

Table 8. Pigment values (ng $\mathrm{l}^{-1}$ ) for surface and bottom suspended particulate matter (SPM) at Banana Reef and Mingulay 1. Mean \pm 1 SD (in parentheses), $\mathrm{n}=$ 5 and $\mathrm{n}=14$ for surface and bottom SPM, respectively. The ratio chl a: $\sum$ phaeopigments is also given

\begin{tabular}{|lccccc|}
\hline \multirow{2}{*}{ Phytopigment } & \multicolumn{2}{c}{ Banana Reef } & & \multicolumn{2}{c|}{ Mingulay 1 } \\
\cline { 2 - 3 } & \multicolumn{2}{c}{ Surface } & Bottom & Surface & Bottom \\
\hline Chlorophyll $c_{3}$ & $29.2(7.1)$ & $1.9(0.7)$ & $29.1(7.2)$ & $2.8(1.7)$ \\
Chlorophyll $c_{1}$ & $11.4(5.0)$ & $1.8(0.7)$ & $15.2(4.3)$ & $2.4(2.3)$ \\
Chlorophyll $c_{2}$ & $482.1(241.2)$ & $54.7(14.8)$ & $546.2(129.4)$ & $60.7(23.0)$ \\
Fucoxanthin & $21.9(13.4)$ & $4.0(1.1)$ & $25.9(6.4)$ & $4.9(1.5)$ \\
19'-Hexanoyloxyfucox. & $18.6(5.2)$ & $0.6(0.1)$ & $19.6(6.3)$ & \\
Diadinoxanthin & $4.8(1.0)$ & $0.3(0.1)$ & $4.4(1.0)$ & $0.3(0.1)$ \\
Chlorophyll $b$ & $42.6(11.3)$ & $1.3(0.8)$ & $45.6(24.3)$ & $2.6(1.9)$ \\
Chlorophyll $a$ & $1234.4(1035.6)$ & $113.4(47.0)$ & $1031.6(236.2)$ & $109.5(51.2)$ \\
$\beta, \beta$-Carotene & $0.8(0.3)$ & $0.1(0.0)$ & $0.8(0.2)$ & $0.3(0.8)$ \\
Phaeophorbide- $a$ & & $4.7(1.8)$ & & $4.9(1.8)$ \\
Phaeophytin- $a$ & $17.0(21.3)$ & $10.0(3.1)$ & $8.1(2.8)$ & $9.7(4.3)$ \\
Chl $a:$ : phaeopigments & $41.0(48.9)$ & $7.6(2.4)$ & $137.6(48.0)$ & $8.1(3.5)$ \\
\hline
\end{tabular}

advection of deep bottom water onto the top of the reef, visible as an increase in turbidity during peak flood and ebb currents. Because of the lower fluorescence, this mechanism probably supplied organic matter of lower quality. Concurrently with the above study on particle supply mechanisms, Dodds et al. (2009) suggested a third possible food source. They used lipid biomarkers to investigate food sources of Lophelia pertusa at Mingulay 1 Reef, and concluded that the corals were mainly feeding on calanoid copepods. However, there are presently no field observations on zooplankton distribution to support this claim.

At Mingulay 1 Reef, Davies et al. (2009) proposed 2 mechanisms for the transport of particulate organic matter to the coral community. One consisted of a rapid downwelling of surface water, caused by an internal wave generated by peak tide and released during the slack tide. This wave is evident at the reef top as a pulse of warmer water that may persist for up to $3 \mathrm{~h}$. This mechanism was assumed to supply higher quality $\mathrm{OM}$ at Mingulay 1 as the warmer water is more fluorescent than ambient bottom water. The second delivery of particulate organic matter to the reef was hypothesized to occur through
After discovering the deeper Banana Reef in 2006, which seemed to differ in its coral community cover from Mingulay 1 Reef, questions were raised concerning the environmental conditions, food supply and trophic position of the local community. The formal analysis of the underwater video records confirmed the impression that on Banana Reef the living coral cover was much denser (living framework per reef length), and the absolute length of live coral framework along the reef was twice that of Mingulay 1 Reef. In contrast to the more homogenous distribution of live coral along Banana Reef, coral was more 
patchily distributed at Mingulay 1 Reef. The highest concentration of live coral on Mingulay 1 Reef was found on transects D and E traversing the gap between the eastern and western ridge (Fig. 2) (Watmough 2008). Also the associated megafauna differed between the reefs with more sponges and galatheid crabs observed at Mingulay 1 Reef.

We subsequently searched for differences between the environmental settings and particle supply that might explain the observed differences. The moorings that we deployed showed different maxima in current speed with higher values at Banana Reef. The effect of current speed on feeding of Lophelia pertusa is still a matter of discussion. On the basis of observations in aquarium specimens, Mortensen (2001) suggests that flow speeds $>5 \mathrm{~cm} \mathrm{~s}^{-1}$ may negatively affect food uptake by $L$. pertusa. In laboratory experiments by Purser et al. (2010), L. pertusa attained higher capture rates of Artemia salina nauplii at low flows $\left(2.5 \mathrm{~cm} \mathrm{~s}^{-1}\right)$ than at higher flows $(5 \mathrm{~cm}$ $\mathrm{s}^{-1}$ ). Capture of live prey by coral polyps probably requires a relatively low speed as the prey can free itself (Purser et al. 2010). In situ video observations on polyps of $L$. pertusa at Mingulay 1 Reef, showed that at the maximum current speed $\left(\sim 40 \mathrm{~cm} \mathrm{~s}^{-1}\right)$, the percentage of extended polyps was at its highest (A.J. Davies pers. obs.). This suggests that the speed range mentioned in Mortensen (2001) and Purser et al. (2010) does not pose the upper limit for feeding on suspended particles (e.g. detritus, algae) at Mingulay 1 Reef. Presently we cannot say if the strong currents on Banana Reef are an impediment to feeding by L. pertusa polyps. High current speeds may have a positive effect aside from supplying suspended particles, especially in conditions with a high suspended load, by keeping corals clear from sediment. A high sediment load can reduce survival of $L$. pertusa as shown by Brooke et al. (2009).

Temperature records from both reefs showed similar 3 mo trends, with maximum temperatures $\sim 0.2^{\circ} \mathrm{C}$ higher at the shallower Mingulay 1 Reef. However, all measured temperatures were well within the NE Atlantic and global thermal ranges for Lophelia pertusa (Davies et al. 2008, Davies \& Guinotte 2011). Unexpectedly, records from the deeper Banana Reef showed tidal temperature and fluorescence peaks that resembled the events generated by the hydraulic jump over Mingulay 1, suggesting that a comparable hydraulic jump occurs over Banana Reef. However, the coupling between major temperature peaks and the tidal cycle at Banana Reef was different from Mingulay 1, i.e. $\sim 4.5 \mathrm{~h}$ and $1 \mathrm{~h}$ after flood to ebb slack, respectively. The average $\sim 3.5 \mathrm{~h}$ delay between major temperature peaks on the 2 reefs (Fig. $7 \mathrm{C}$ ) is about equal to the time it takes water to cross the shortest distance between the reefs in SW direction $(1.7 \mathrm{~km})$ with the average ebb current speed (Mingulay 1 Reef, $\sim 0.5 \mathrm{~km} \mathrm{~h}^{-1}$ ). It is therefore likely that the strong $12 \mathrm{~h}$ temperature cycle at Banana Reef could be explained as the propagation of downwelled water generated by the hydraulic jump at Mingulay 1 Reef, which travels to Banana Reef with the ebb tide. In this scenario, the weaker $6 \mathrm{~h}$ temperature signal is possibly a result of tidal displacement of the more pronounced temperature signal from the $12 \mathrm{~h}$ cycle, as it travels back and forth across the reef with the tide. If the above mechanisms of water (and particle) transport are true, then the particle quality at Banana Reef would be similar or lower than at Mingulay 1, and accordingly this does not explain the higher coral density at Banana Reef.

Due to logistic constraints our comparative study of SPM covered only a short period in the summer, and sampling could not be conducted simultaneously on the 2 reefs. Hence our data only hold for a limited period and cannot be extrapolated without further measurements. Despite these shortcomings, our study revealed significant insight into relationships between corals, SPM and reef location at the time of our study. In the earlier study, Davies et al. (2009) hypothesized that bottom SPM visible as turbidity peaks on Mingulay 1 Reef during peak flood and ebb, might form a potential food source for Lophelia pertusa. In contrast to surface SPM which had $\delta^{13} \mathrm{C}$ signatures in the range reported for surface SPM both in the North Atlantic and a Scottish marine loch (Iken et al. 2001, Loh et al. 2008), bottom SPM at both reefs was distinctively enriched in ${ }^{13} \mathrm{C}$, particularly at Banana Reef (Table 5). One explanation for this marked difference could be that bottom SPM is composed of aged organic material and hence enriched in ${ }^{13} \mathrm{C}$ (e.g. Laane et al. 1990, Megens et al. 2001). A second explanation could be the presence of macroalgal detritus. Common species of brown and red algae in the NE Atlantic, e.g. Laminaria digitata and Palmaria palmata, have relatively high $\delta^{13} \mathrm{C}$ values of $\sim-15 \%$ (Schaal et al. 2010). Similarly as with $\delta^{13} \mathrm{C}$, SPM in bottom samples was enriched in $\delta^{15} \mathrm{~N}$ compared to surface SPM, and $\delta^{15} \mathrm{~N}$ values in bottom SPM corresponded with those of macroalgae detritus (Schaal et al. 2010). Lower quality of bottom SPM was evident from lipid distributions having lower quantities of labile PUFAs and phytoplankton biomarkers (Table 6, Fig. 8A,B). Also, the bacterial degradation index $\mathrm{C}_{18: 1(\mathrm{n}-9)}: \mathrm{C}_{18: 1(\mathrm{n}-7)}$ was higher in bottom SPM, indicating more degraded material 
(Fig. 9D). Furthermore, bottom SPM also had a much lower chl a: phaeopigments ratio compared to surface SPM, again suggesting a higher level of degradation (Table 8).

The above data indicate that the organic fraction of SPM at the bottom is on average more degraded than at the surface and probably less nutritious for the corals. More evidence that corals did not thrive on organic carbon in bottom SPM collected during our study comes from the $\delta^{13} \mathrm{C}$ signatures of Lophelia pertusa tissue, which were depleted relative to those of bottom SPM (Table 5). Meta-analyses of trophic fractionation in aquatic organisms show that consumers generally become enriched in $\delta^{13} \mathrm{C}$ relative to their diet, with 0.5 to $1 \%$ on average (e.g. Post 2002, McCutchan et al. 2003, France \& Peters 2011). Despite considerable variability in fractionation, including negative values (Yokoyama et al. 2005), the negative value in $L$. pertusa with respect to bottom SPM ( $>-5 \%$, Table 5$)$ fall outside the reported range. We therefore conclude that bottom SPM is not a principal carbon source for the corals in the study period. In contrast, $\delta^{13} \mathrm{C}$ signatures of surface SPM and corals on both reefs are more in line with the presumed trophic fractionation in ${ }^{13} \mathrm{C}$. The $\delta^{15} \mathrm{~N}$ signatures of $L$. pertusa found in this study fit well inside the range observed for other NE Atlantic coral habitats (Voss et al. 1996, Kiriakoulakis et al. 2005, Duineveld et al. 2007). Both surface and bottom SPM samples were depleted in ${ }^{15} \mathrm{~N}$ compared to coral tissue (Table 5). However, $\delta^{15} \mathrm{~N}$ signatures of surface SPM fit better as the $\mathrm{N}$ source of the corals when adopting a trophic fractionation for aquatic animals of 3 to $4 \%$ (Post 2002, Yokoyama et al. 2005, France \& Peters 2011). From FA analysis, Dodds et al. (2009) concluded that $L$. pertusa at Mingualy 1 reef feeds predominantly on pelagic calanoid copepods. This is not entirely supported by our stable isotope analysis of the copepods that we collected. The difference between mean $\delta^{13} \mathrm{C}$ values of copepods $(-21.5 \%$ ) and L. pertusa, i.e. $1 \%$, was close to the enrichment accepted for marine organisms (e.g. France \& Peters 2011). It should be emphasized that range of reported $\delta^{13} \mathrm{C}$ enrichment is quite small (see above), and samples of both copepods and corals show a degree of variation (Table 5). The $\delta^{15} \mathrm{~N}$ values of copepods were on average $\sim 1.5 \%$ lower than those of $L$. pertusa. The latter value is distinctly less than the average trophic step, suggesting that copepods do not make up the major part of the nitrogen source of corals, at least at the time of our measurements.

The above results support the conclusion that Lophelia pertusa heavily utilises fresh organic matter from surface SPM. This is confirmed by lipid analysis of $L$. pertusa tissue. The percentage composition of the lipid pools in corals from Mingulay 1 and Banana reefs were quite similar and dominated by PUFAs (Fig. 8D). Additionally, the PUFA:MUFA ratio was higher in the corals than in SPM (Fig. 9B) suggesting a proportionally greater input of algae rich in PUFAs to the diet relative to zooplankton which generally contains higher amounts of MUFAs (Graeve et al. 1994). At both reefs, L. pertusa tissue had substantial proportions of microalgal biomarkers, e.g. phytosterols and 2 FAs: $\mathrm{C}_{20: 5(\mathrm{n}-3)}$ and $\mathrm{C}_{22: 6(\mathrm{n}-3)}$ (Fig. 9E). Furthermore, the ratio of the microalgal biomarkers $\mathrm{C}_{22: 6(\mathrm{n}-3)}: \mathrm{C}_{20: 5(\mathrm{n}-3)}$ in L. pertusa corresponded well with that of surface SPM, pointing to consumption of fresh phytoplankton (Fig. 9C). Although our $\delta^{15} \mathrm{~N}$ values of planktonic copepods and $L$. pertusa tissue suggests that zooplankton does not form a major part of the diet during the period of sampling, some zooplankton is consumed by $L$. pertusa as evident from the presence of monounsaturated alcohols or FAs $\left(\mathrm{C}_{20: 1}\right.$ and $\left.\mathrm{C}_{22: 1}\right)$ in its tissues and the relatively high values for the zooplankton lipid indices compared to SPM (Fig. 9F). Values of the bacterial lipid index were much lower in the corals than in the SPM indicating that bacteria are not an important component of the food assimilated by L. pertusa (Fig. 9G).

Despite overall correspondence in the proportional lipid profiles of Lophelia pertusa at the 2 reefs (Fig. 8D), there were marked differences in concentrations of total FA, mono-unsaturated alcohols, MUFAs and PUFAs all of which were lower in L. pertusa from Banana Reef (Fig. 8C). This was especially evident in PUFAs and cannot be easily explained by the differences in supply of fresh SPM to the 2 reefs (Fig. 8A,B). The fluorometers that we deployed for 3 mo at the 2 reefs yielded almost similar curves (Fig. 5A,B) with only a $3 \%$ difference in the integrated chl a values over the whole period. Furthermore, at the time of sampling neither chl $a$ : $\Sigma$ pheopigments ratios nor isotope signatures of SPM showed striking between-reef differences in quality or age of SPM that can explain why corals at Banana Reef ingest fewer particles rich in PUFAs than on Mingulay 1. Differences in concentrations of PUFAs in L. pertusa at the 2 reefs could also arise from differences in their utilization for reproductive tissue. Earlier, Waller \& Tyler (2005) found that small L. pertusa colonies at the Darwin Mounds did not reproduce, in contrast to well developed colonies in the Porcupine Seabight. A comparative study of reproduction on Banana and Mingulay 1 
reefs could shed further light on the differences in polyp condition and their use of biomarkers such as PUFAs.

None of our data seem to provide a clear and straightforward answer for the difference in coral abundance between the reefs. In fact, the higher concentrations of lipids in corals and SPM (Fig. 8A,C) at Mingulay 1 Reef plus the evidence that the fresh downwelling pulse descends over Mingulay 1 before reaching Banana Reef, suggest that food conditions are better at Mingulay 1 than at Banana Reef. However, we speculate that differences in tidal current speeds and temperature recorded at the reefs may be an explanatory factor for the coral coverage. (1) The elevated currents at Banana Reef might assist polyps in shedding suspended sediment that would otherwise be retained on the coral framework (e.g. Brooke et al. 2009, Larsson \& Purser 2011). This is likely important in a high turbidity environment such as our study area with natural SPM levels $>1.7 \mathrm{mg} \mathrm{l}^{-1}$. (2) These elevated currents may also increase the particle encounter rate at Banana Reef compared to Mingulay 1 Reef. (3) Cnidarian physiology is strongly linked to temperature, with only slight increases exponentially driving metabolic rates (Dodds et al. 2007). This means that to survive at the slightly higher temperatures at Mingulay 1 Reef, corals will need a richer food supply than those that reside in the colder waters of Banana Reef. With food supplies being equal at the 2 reefs, a greater energy demand of corals at Mingulay 1 might explain a less well developed reef.

This study is amongst only a few attempts to disentangle the complex interaction between hydrography, food supply and cold-water coral reefs by actual measurements rather than inferences about particle delivery by enhanced currents. We have provided evidence that corals at the 2 reefs primarily feed on the same fresh particles from the surface layer (phytoplankton and limited amounts of zooplankton), and we have revealed potential supply mechanisms. The reason(s) for the distinct difference in coral cover between reefs remains unresolved, although current speed, temperature and sediment loading could play a major role(s).

Acknowledgements. We thank the crew of RV Pelagia for their dedication and assistance in collecting the field data. We extend our thanks to Prof. G. Wolff and Dr. A. Thompson (University of Liverpool) for assistance with the lipid analyses and Dr. S. Brooks (Isoanalytical, Crewe) for the stable isotope analyses. The research leading to these results has received funding from the European Community's Seventh Framework Programme (FP7/2007-2013) under the HER-
MIONE project, grant agreement no. 226354. The shiptime for this study was granted by Royal NIOZ.

\section{LITERATURE CITED}

Benn AR, Weaver PP, Billet DSM, van den Hove S, Murdock AP, Doneghan GB, Le Bas T (2010) Human activities on the deep seafloor in the North East Atlantic: an assessment of spatial extent. PLoS ONE 5:e12730. doi:10.1371/ journal.pone.0012730

Brooke SD, Holmes MW, Young CM (2009) Sediment tolerance of two different morphotypes of the deep-sea coral Lophelia pertusa from the Gulf of Mexico. Mar Ecol Prog Ser 390:137-144

Carlier A, Le Guilloux E, Olu K, Sarrazin J, Mastrototaro F, Taviani M, Clavier J (2009) Trophic relationships in a deep Mediterranean cold-water coral bank (Santa Maria di Leuca, Ionian Sea). Mar Ecol Prog Ser 397: 125-137

Clarke KR, Warwick RM (2001) Change in marine communities: an approach to statistical analysis and interpretation. PRIMER-E 2nd edition, Plymouth

Conte MH, Thompson A, Eglinton G (1994) Primary production of lipid biomarker compounds by Emiliana huxleyi: results from an experimental mesocosm study in fjords of Southwestern Norway. Sarsia 79:319-331

> Dalsgaard J, St John M, Kattner G, Muller-Navarra D, Hagen W (2003) Fatty acid trophic markers in the pelagic marine environment. Adv Mar Biol 46:225-340

Davies AJ, Guinotte JM (2011) Global habitat suitability for framework-forming cold-water corals. PLoS ONE 6:e18483 10.1371/journal.pone.0018483

Davies AJ, Wisshak M, Orr JC, Roberts JM (2008) Predicting suitable habitat for the cold-water reef frameworkforming coral Lophelia pertusa (Scleractinia). Deep-Sea Res I 55:1048-1062

> Davies A, Duineveld G, Lavaleye M, Bergman M, van Haren H, Roberts J (2009) Downwelling and deep-water bottom currents as food supply mechanisms to the cold-water coral Lophelia pertusa (Scleractinia) at the Mingulay Reef complex. Limnol Oceanogr 54:620-629

de Haas H, Mienis F, Frank N, Richter TO and others (2009) Morphology and sedimentology of (clustered) cold-water coral mounds at the south Rockall Trough margins, NE Atlantic Ocean. Facies 55:1-26

> Dodds LA, Roberts JM, Taylor AC, Marubini F (2007) The cold-water coral Lophelia pertusa (Scleractinia) reveals metabolic tolerance to temperature and dissolved oxygen change. J Exp Mar Biol Ecol 349:205-214

> Dodds LA, Black KD, Orr H, Roberts JM (2009) Lipid biomarkers reveal geographical differences in food supply to the cold-water coral Lophelia pertusa (Scleractinia). Mar Ecol Prog Ser 397:113-124

> Duineveld G, Lavaleye M, Berghuis E (2004) Particle flux and food supply to a seamount cold-water coral community (Galicia Bank, NW Spain). Mar Ecol Prog Ser 277: 13-23

Duineveld G, Lavaleye M, Bergman M, De Stigter H, Mienis F (2007) Trophic structure of a cold-water coral mound community (Rockall Bank, NE Atlantic) in relation to the near-bottom particle supply and current regime. Bull Mar Sci 81:449-467

> France RL, Peters RH (1997) Ecosystem differences in the trophic enrichment of $13 \mathrm{C}$ in aquatic food webs. Can J Fish Aquat Sci 54:1255-1258 
Fry B (2006) Stable isotope ecology. Springer, New York

Fry B, Sherr EB (1984) Delta-C-13 measurements as indicators of carbon flow in marine and fresh-water ecosystems. Contrib Mar Sci 27:13-47

Gillan FT, Johns RB (1986) Chemical markers for marine bacteria: fatty acids and pigments. In: Johns RB (ed) Biological markers in the sedimentary environment. Elsevier, New York, p 291-309

Graeve M, Hagen W, Kattner G (1994) Herbivorous or omnivorous? On the significance of lipid compositions as trophic markers in Antarctic copepods. Deep-Sea Res I 41:915-924

Graeve M, Kattner G, Piepenburg D (1997) Lipids in Arctic benthos: Does the fatty acid and alcohol composition reflect feeding and trophic interactions? Polar Biol 18:53-61

Hall-Spencer J, Allain V, Fosså JH (2002) Trawling damage to Northeast Atlantic ancient coral reefs. Proc R Soc Lond B 269:507-511

> Hall-Spencer JM, Tasker M, Soffker M, Christiansen S and others (2009) Design of marine protected areas on high seas and territorial waters of Rockall Bank. Mar Ecol Prog Ser 397:305-308

Harwood JL, Russell NJ (1984) Lipids in plants and microorganisms. George Allen \& Unwin, London

Hayakawa K, Handa N, Wong CS (1997) Changes in the composition of fatty acids in sinking matter during a diatom bloom in a controlled experimental ecosystem. J Exp Mar Biol Ecol 208:29-43

> Henry LA, Davies AJ, Roberts JM (2010) Beta diversity of cold-water coral reef communities off western Scotland. Coral Reefs 29:427-436

> Iken K, Brey T, Wand U, Voigt J, Junghans P (2001) Food web structure of the benthic community at the Porcupine Abyssal Plain (NE Atlantic): a stable isotope analysis. Prog Oceanogr 50:383-405

> Jeffreys RM, Wolff GA, Cowie GL (2009) Influence of oxygen on heterotrophic reworking of sedimentary lipids at the Pakistan Margin. Deep-Sea Res II 56:358-375

Jensen A, Frederiksen R (1992) The fauna associated with the Bank-Forming deep-water coral Lophelia pertusa (Scleractinaria) on the Faroe Shelf. Sarsia 77:53-69

> Jonsson L, Nilsson P, Floruta F, Lundälv T (2004) Distributional patterns of macro- and megafauna associated with a reef of the cold-water coral Lophelia pertusa on the Swedish west coast. Mar Ecol Prog Ser 284:163-171

Kiriakoulakis K, Bett B, White M, Wolff G (2004) Organic biogeochemistry of the Darwin Mounds, a deep-water coral ecosystem, of the NE Atlantic. Deep-Sea Res I 51:1937-1954

Kiriakoulakis K, Fisher EH, Wolff GA, Freiwald A and others (2005) Lipids and nitrogen isotopes of two deep-water corals from the North-East Atlantic: initial results and implications for their nutrition. In: Freiwald A, Roberts JM (eds) Cold-water corals and ecosystems. Springer, Berlin, p 715-729

Laane R, Turkstra E, Mook W (1990) Stable carbon isotope composition of pelagic and benthic organic matter in the North Sea and adjacent estuaries. In: Ittekot V, Kempe S, Michaelis W, Spitzy A (eds) Facets of modern biogeochemistry. Springer, Berlin, p 214-224

Larsson AI, Purser A (2011) Sedimentation on the cold-water coral Lophelia pertusa: cleaning efficiency from natural sediments and drill cuttings. Mar Pollut Bull 62: 1159-1168
Lavaleye M, Duineveld G, Berghuis E, Kok A, Witbaard R (2002) A comparison between the megafauna communities on the NW Iberian and Celtic continental margins effects of coastal upwelling? Prog Oceanogr 52:459-476

> Lee C, Wakeham SG, Hedges JI (2000) Composition and flux of particulate amino acids and chloropigments in equatorial Pacific seawater and sediments. Deep-Sea Res I 47:1535-1568

> Lessard-Pilon SA, Podowski EL, Cordes EE, Fisher CR (2010) Megafauna community composition associated with Lophelia pertusa colonies in the Gulf of Mexico. Deep-Sea Res II 57:1882-1890

Loh PS, Reeves AD, Harvey SM, Overnell J, Miller AEJ (2008) The fate of terrestrial organic matter in two Scottish sea lochs. Estuar Coast Shelf Sci 76:566-579

McCutchan JH Jr, Lewis WM Jr, Kendall C, McGrath CC (2003) Variation in trophic shift for stable isotope ratios of carbon, nitrogen, and sulfur. Oikos 102:378-390

- Megens L, van der Plicht J, de Leeuw JW (2001) Temporal variations in $13 \mathrm{C}$ and $14 \mathrm{C}$ concentrations in particulate organic matter from the southern North Sea. Geochim Cosmochim Acta 65:2899-2911

Mienis F, de Stigter HC, White M, Duineveld G and others (2007) Hydrodynamic controls on cold-water coral growth and carbonate-mound development at the SW and SE Rockall trough margin, NE Atlantic ocean. DeepSea Res I 54:1655-1674

Mortensen PB (2001) Aquarium observations on the deepwater coral Lophelia pertusa (L., 1758) (Scleractinia) and selected associated invertebrates. Ophelia 54:83-104

Post D (2002) Using stable isotopes to estimate trophic position: models, methods, and assumptions. Ecology 83: 703-718

Press WH, Teukolsky SA, Vetterling WT, Flannery BP (1992) Numerical recipes in C. The art of scientific computing. Cambridge University Press, Cambridge, p 994

Purser A, Larsson AI, Thomsen L, van Oevelen D (2010) The influence of flow velocity and food concentration on $\mathrm{Lo}$ phelia pertusa (Scleractinia) zooplankton capture rates. J Exp Mar Biol Ecol 395:55-62

> Roberts JM, Brown CJ, Long D, Bates CR (2005) Acoustic mapping using a multibeam echosounder reveals coldwater coral reefs and surrounding habitats. Coral Reefs 24:654-669

> Roberts JM, Davies AJ, Henry LA, Dodds LA and others (2009) Mingulay reef complex: an interdisciplinary study of cold-water coral habitat, hydrography and biodiversity. Mar Ecol Prog Ser 397:139-151

Ruhl HA (2008) Community change in the variable resource habitat of the abyssal northeast Pacific. Ecology 89: 991-1000

Ruhl HA, Smith Jr KL (2004) Shifts in deep-sea community structure linked to climate and food supply. Science 305:513-515

Santos V, Billett DSM, Rice AL, Wolff GA (1994) Organic matter in deep-sea sediments from the porcupine abyssal-plain in the Northeast Atlantic-Ocean 1. Lipids. Deep-Sea Res I 41:787-819

Sargent JR (1976) The structure, metabolism and function of lipids in marine organisms. In: Malins DC, Sargent JR (eds) Biochemical and biophysical perspectives in marine biology, Volume 3. Academic Press, London, p 149-212

Schaal G, Riera P, Leroux C (2010) Trophic ecology in a Northern Brittany (Batz Island, France) kelp (Laminaria 
digitata) forest, as investigated through stable isotopes and chemical assays. J Sea Res 63:24-35

Schubert CJ, Niggemann J, Klockgether G, Ferdelman TG (2005) Chlorin index: a new parameter for organic matter freshness in sediments. Geochem Geophys Geosyst 6:Q03005. doi:10.1029/2004GC000837

Thiem O, Ravagnan E, Fossa JH, Berntsen J (2006) Food supply mechanisms for cold-water corals along a continental shelf edge. J Mar Syst 60:207-219

> Volkman JK, Johns RB (1977) Geochemical significance of positional isomers of unsaturated acids from an intertidal zone sediment. Nature 267:693-694

Volkman JK, Barrett SM, Blackburn SI, Mansour MP, Sikes EL, Gelin F (1998) Microalgal biomarkers: a review of recent research developments. Org Geochem 29: 1163-1179

Voss M, Altabet M, Bodungen B (1996) Delta15N in sedimenting particles as indicator of euphotic-zone processes. Deep-Sea Res I 43:33-47

Wagner H, Purser A, Thomsen L, Jesus CC, Lundalv T (2011) Particulate organic matter fluxes and hydrodynamics at the Tisler cold-water coral reef. J Mar Syst 85:19-29

Wakeham S, Hedges J, Lee C, Peterson M, Hernes P (1997) Compositions and transport of lipid biomarkers through the water column and surficial sediments of the equatorial Pacific Ocean. Deep-Sea Res II 44:2131-2162

Waller RG, Tyler PA (2005) The reproductive biology of two deep-water, reef-building scleractinians from the NE Atlantic Ocean. Coral Reefs 24:514-522

Watmough T (2008) Mapping the Mingulay Reef complex and developing video analysis techniques for deepsea research. MSc thesis, Herriot-Watt University, Edinburgh

Editorial responsibility: Karen Miller, Hobart, Australia
Weaver PPE, Billett DSM, Boetius A, Danovaro R and others (2004) Hotspot ecosystem research on Europe's deepocean margins. Oceanography 17:132-143

Weaver PPE, Boetius A, Danovaro R, Freiwald A and others (2009) The future of integrated deep-sea research in Europe: the HERMIONE Project. Oceanography 22: 178-191

White M, Dorschel B (2010) The importance of the permanent thermocline to the cold water coral carbonate mound distribution in the NE Atlantic. Earth Planet Sci Lett 296:395-402

White M, Mohn C, de Stigter H, Mottram G (2005) Deepwater coral development as a function of hydrodynamics and surface productivity around the submarine banks of the Rockall Trough, NE Atlantic. In: Freiwald A, Roberts JM (eds) Cold-water corals and ecosystems. Springer, Berlin, p 503-514

Wienberg C, Beuck L, Heidkamp S, Hebbeln D and others (2008) Franken Mound: facies and biocoenoses on a newly-discovered 'carbonate mound' on the western Rockall Bank, NE Atlantic. Facies 54:1-24

> Wigham B, Hudson I, Billett D, Wolff G (2003) Is long-term change in the abyssal Northeast Atlantic driven by qualitative changes in export flux? Evidence from selective feeding in deep-sea holothurians. Prog Oceanogr 59: 409-441

> Witte U, Wenzhofer F, Sommer S, Boetius A and others (2003) In situ experimental evidence of the fate of a phytodetritus pulse at the abyssal sea floor. Nature 424 : 763-766

Yokoyama H, Tamaki A, Harada K, Shimoda K, Koyama K, Ishihi Y (2005) Variability of diet-tissue isotopic fractionation in estuarine macrobenthos. Mar Ecol Prog Ser 296: $115-128$

Submitted: May 19, 2011; Accepted: September 29, 2011 Proofs received from author(s): December 20, 2011 